\title{
Effect of Injection Timing In Reducing The Harmful Pollutants Emitted From Cl Engine Using N-Butanol Antioxidant Blended Eco-Friendly Mahua Biodiesel
}

Isaac JoshuaRamesh Lalvani Joshua Stephen Chellakumar ( $\square$ isaac.jrl@amu.edu.et)

Arba Minch Institute of Technology, Arba Minch University

Elumalai P V

Aditya Engineering College, Surampalem. East Godavari - 533437, Andhra Pradesh

M Parthasarathy

Vel Tech Rangarajan Dr.Sagunthala R\&D Institute of Science and Technology

\section{Research Article}

Keywords: Mahua biodiesel, n-butanol, injection timing, pollutant, emission

Posted Date: July 1st, 2021

DOI: https://doi.org/10.21203/rs.3.rs-654120/v1

License: (c) (i) This work is licensed under a Creative Commons Attribution 4.0 International License.

Read Full License 


\section{Abstract}

Consuming non-renewable energy sources has genuine and long-standing unfavorable consequences on people's health, neighborhood networks and ecosystems, and also on the worldwide atmosphere. The burgeoning demand and use of diesel engines in various fields cause emission of exhaust gases like NOx and $\mathrm{CO}$ that lead to serious environmental pollution and hazards like global warming, respiratory problems, and so on, has necessitated a reduction in the use of diesel and addition of suitable biodiesel. Mahua biodiesel blend has also been considered as a safe renewable fuel for conventional engines. This is due to its desirable properties such as rapid growth rate, higher productivity, and the ability to utilize $\mathrm{CO}_{2}$ into fuel. The introduction of an antioxidant, preferably n-butanol eliminates these harmful emissions from the diesel engine. In this experimental investigation, mahua biodiesel blend mixed with $\mathrm{n}$ butanol has been used as test fuel in a conventional engine. Because of the special character $n$-butanol has been chosen for use with the mahua biodiesel blend. About 20-30 vol.\% of n-butanol has been blended with 80 vol.\% of diesel and tested. The manufacturer set injection timing was $23^{\circ} \mathrm{CA}$ bTDC. The injection timing is preferably between $21^{\circ} \mathrm{CA}$ bTDC and $25^{\circ} \mathrm{CA}$ bTDC. Nitrogen oxides and carbon monoxide are reduced by 49 percent and 5.88 percent, respectively, when a blend of $B 20+D 80+30 \% n-$ butanol is used at $21^{\circ} \mathrm{CA} \mathrm{bTDC}$ relative to diesel fuel. The smoke and hydrocarbon emission of blend B20 + D80 + 30\% n-butanol at $25^{\circ} \mathrm{CA}$ bTDC is reduced by $40 \%$ and $38.07 \%$, respectively, related to diesel. The brake thermal efficiency for entire injection timing has been identified to be increased correlated to all other test blends. The brake thermal efficiency in blend B20 + D $80+30 \% n$-butanol of $25^{\circ} \mathrm{CA}$ bTDC is increased by $15.30 \%$, when compared with diesel fuel. These promising results assure that mahua biodiesel blend containing antioxidant would be eco-friendly fuel.

\section{Introduction}

Experts are scrambling to find suitable replacement energy options, which have grown in importance due to rising energy needs and pollution. [1]. A few environmental issues emerge because of the utilization energy sources in IC engines. Biodiesel is a fuel delivered from vegetable oils utilizing a couple of catalysts. Biodiesel is an alternative solution to the problem faced by most developing countries [2]. Biodiesel has been select by many kinds of research as far as maintainability, financial, and environmentally friendly behavior [3]. To produce sustainable biodiesel on a large scale, it is imperative to understand the advantage of utilizing minimal effort non-edible oil that can cut down the expense of delivering biodiesel [4]. Rudolf diesel, with his engine powered by peanut oil, wrote, "The use of vegetable oil in diesel engine fuel may appear to be inconsequential now, but in the future it might turn out to be just as essential as conventional oil." [5]. It is notable that non-renewable energy sources are effectively approachable in a few locations around the globe. Several researchers have been making systematic effort to utilize plant oils as engine fuel. This will also lessen the need for fossil fuel and emission of harmful wastes into the atmosphere, because they are organic and emissions-less. The raw vegetable oils have the highest significance and exist as a promising substitute for fossil fuels [6]. They have high viscosity, lower heat capacity, and are well known for gum formation, auto oxidation, and lower engine 
durability. Without any changes to the engine, the use of these oils may lead to poor performance and engine damage. Contamination forms and adheres to piston rings due to the direct usage of vegetable oil. It will be necessary to put in place some preparatory activities in order to make vegetable oils a viable fuel. Several methods are available for making vegetable oils usable, Among these, transesterification is the most popular method of extracting biodiesel.

In a previous study, the palm and jatropha biodiesel are extracted from the transesterification process. The combination of palm biodiesel and jatropha biodiesel each $5 \%$ when mixed with $90 \%$ of diesel and palm biodiesel and jatropha biodiesel each $10 \%$ when mixed with $80 \%$ of diesel gave better performance when compared with other tested fuel. These two fuels blend shows slightly increased brake specific fuel consumption (BSFC) then correlated with diesel. Apart from this the emission characteristics have been reduced mainly because of more injection of fuel through the inlet manifold. The oxides of nitrogen (NOx) and hydrocarbon (HC) emission for blend of palm and jatropha biodiesel each $5 \%$ mixed with $90 \%$ of diesel were decreased by $9.53 \%$ and $3.69 \%$, respectively, when used in conjunction with mineral diesel fuel. The carbon monoxide ( $\mathrm{CO})$ and carbon dioxide $\left(\mathrm{CO}_{2}\right)$ of blend palm and jatropha biodiesel each $5 \%$ mixed with $90 \%$ of diesel were decreased by $20.49 \%$ and $5.69 \%$, respectively, when used in conjunction with mineral diesel fuel due to the proper combustion and shorten ignition delay [7].

The rape seed oil was separated by transesterification process and mixed with $80 \%$ and $90 \%$ of base fuel and fuel mixes were prepared, such as B10 and B20, respectively, at a different speed to run the base diesel engine. At $1800 \mathrm{rpm}$ the mix B10 demonstrated the diminished BSFC when contrasted with the diesel fuel due to the lesser heating value and improved the ignition process. The emission of $\mathrm{CO}$ and $\mathrm{HC}$ were cut down when the fuel blends of B10 were used at 75\% of load condition at $3000 \mathrm{rpm}$, owing to the oxygen concentration of biodiesel and appropriate ignition timing. This is mainly due to proper blending of air-fuel through the ignition procedure [8].

The rapeseed oil and mahua oil were mixed equally and a new biodiesel was prepared and this biodiesel has been mixed with the various proportion of diesel having varying percentage of $20 \%, 40 \%, 60 \%$, and $80 \%$, respectively. The blend B20 gave the superior performance and this value near to the base fuel diesel. The brake thermal efficiency (BTE) was decreased by $2.79 \%$, when used in conjunction with mineral base fuel due to the inferior CV and greater viscosity. The emission of CO, smoke opacity, and $\mathrm{HC}$ were decreased by $20.66 \%, 6.9 \%$, and $8.56 \%$, respectively, individually when contrasted with perfect diesel fuel owing to the full combustion and shortened ignition delay. The concentrations of NOx were found to be more by $3.71 \%$ with B20, when contrasted with slick diesel fuel due to higher temperatures produced obtained during the combustion process [9].

In this investigation, the sunflower and soybean oil were mixed $50 \%$ equally and new biodiesel has been prepared. It is mixed with various proportions of diesel preferably $10 \%, 20 \%$, and $30 \%$, respectively. The blends showed slight decrease in cylinder pressure and HRR by $8.1 \%$ and $7.2 \%$, respectively, when compared with neat diesel fuel, because of the lesser CV and lower ID. The CO concentration was decreased by $33.8 \%$ when contrasted with flawless diesel fuel due to better combustion and lesser IT. 
When compared to pure diesel fuel, the $\mathrm{HC}$ emission was shown to be reduced using the B30 fuel mix. The NOx and BSFC were increased by $0.98 \%, 2.5 \%$, and $11.43 \%$ with the fuel bend B30 when compared with the neat base fuel. It is owing to the higher ignition delay and lack of oxygen availability of the biodiesel [10].

Nowadays, many studies have been done focusing on biodiesel with some antioxidant agents like BHT, $\mathrm{BHA}$, n-butanol, n-octanol, and so on, to improvement performance and decreased emission attributes of the diesel engine. When using the antioxidants there is a drastic decrease in NOx and slightly increase in BTE.

In this investigation, Calophyllum inophyllum was chosen as the biodiesel, mixed with antioxidants, preferably BHT 500 ppm of dosage, and nanoadditives of titanium oxide of 100 ppm dosage and was used in the direct ignition diesel engine. The inclusion of nanoparticles and BHT into the fuel showed slight increase in BTE by $4 \%$ and $2 \%$, respectively, then correlated to the neat diesel fuel due to the oxygen availability in the nanoparticles and higher the density of the fuel. The CLME with BHT of fuel blend showed increase in emission of $\mathrm{HC}$ and $\mathrm{CO}$ by $35 \%$ and $12.76 \%$, respectively, when compared with pure C100 due to the availability of free radical surface and decreased oxidation of HC. The NOx concentration was drastically reduced by $11.85 \%$ when adding the antioxidants $(\mathrm{BHT})$ with the fuel, when compared with other tested fuels due to the oxidation during the combustion process [11].

In this study mahua oil extracted by transesterification process was mixed with the antioxidants (BHT) in various proportions, such as $5 \%, 10 \%$, and $15 \%$, and was then used for investigation. The BTE was found to be slightly increased by $3.42 \%$ with the blends $B 85$, when contrasted with the raw diesel fuel. The blend B85 showed a decrease in $\mathrm{HC}$ and smoke opacity by $37.63 \%$ and $2.65 \%$, respectively, when contrasted with the mineral fuel, because of the greater oxygen content available in the fuel and proper combustion. The concentration of $\mathrm{NO}_{x}$ and EGT were found to increase in the B85 blend by $45.87 \%$ and $27.33 \%$, respectively, when contrasted with diesel fuel, this was mainly because of the high temperature produced during the combustion process [12].

The coconut biodiesel extracted by the transesterification method is mixed with the antioxidants such as BHT and BHA at a dosage of 2000 ppm and used for investigation. The results showed significant decrease in NOx and slightly increase in BTE. Addition of BHA in B20 blend showed drastic decrease in NOx by $7.78 \%$, when correlated with the base fuel, because of phenolic hydroxyl present in the antioxidant and oxygen availability in the biodiesel. The blend B20 with BHA showed decreased emission of CO and smoke opacity by $18.39 \%$ and $32.43 \%$, respectively, when correlated with neat base fuel mainly due to the oxygen availability and also due to increase in the $\mathrm{C}-\mathrm{C}$ bond. The B2O blend containing BHT showed highest $\mathrm{HC}$ emission of $27.65 \%$, when correlated with diesel fuel, mainly due to the free radical formation [13].

In another study, the Annona biodiesel and three different antioxidants agents like p-phenylenediamine (PPDA), alpha-tocopherol acetate (AT) and I-ascorbic acid (LA)were investigated. The antioxidants were 
used in a different dosage of 50, 150, 250, 350, and $450 \mathrm{mg}$ and mixed with biodiesel. It was found that all the antioxidants when mixed with the biodiesel showed slight decrease in emission of NOx. Among all the dosage of antioxidants, $250 \mathrm{mg}$ showed a significant decrease in NOx by $24.7 \%, 22 \%$, and $23.8 \%$, respectively, when compared with base fuel, and this is mainly due to the greater cetane number and lesser ignition delay and oxygen availability in the biodiesel. Finally, the results concluded that biodiesel containing $250 \mathrm{mg}$ of PPDA showed drastic reduction in NOx, when correlated with the other two antioxidants [14].

The researchers are also focusing on diesel engine parameters like injection timing, injection pressure, and so on. When using antioxidants mixed with B20 during the injection timing there was a significant decrease in NOx improvement in the performance of the engine, and also improvement in combustion, when compared with the normal base engine.

In another study, the Syzygium cumini oil containing biodiesel was used and experiments were performed at different injection timing and pressure. The blends tested were B30, B70, and B100 to operate the diesel engine. The blend B30 and diesel increased the BTE by $16.68 \%$ and $17.85 \%$, respectively, when the injection timing was $21^{\circ} \mathrm{CA}$ bTDC. When the injection timing was increased, the emission of $\mathrm{HC}$ and $\mathrm{CO}$ in the blend B30 was decreased by $46.15 \%$ and $15.9 \%$, respectively, when compared with other test fuels. In advanced injection timing greatly reduced the smoke opacity emission by $28.7 \%$ in B30 blend, when compared with other test fuels. During the advanced injection timing NOx emission was high, when compared with the normal diesel engine. There was a remarkable reduction in emission of harmful wastes when the injection timing was increased [15].

In another study, the idea was to vary injection timing of the base engine to reduce the NOx emission. By delaying injection to $21^{\circ} \mathrm{CA}$ bTDC from the usual 24oCA bTDC, the hybrid biofuel (jatropha oil and rubber seed oil) was utilized in a single-cylinder base engine. Along with pure diesel fuel, B20 (biodiesel-20 percent), B40 (biodiesel-40 percent), and B60 (biodiesel-60 percent) mixes were utilized. By using this hybrid biofuel, this study article demonstrated the effect of injection time modification in a base engine. The experiments examined the performance and emission characteristics of BSFC, NOx, CO, and unburned hydrocarbon (UHC).It was found from the results that SFC for B20 blend was lesser than for raw base fuel, while B40 and B60 blends had slightly increased values but were similar to the B20 blend. It was also seen that the $\mathrm{CO}$ and $\mathrm{UHC}$ ) emissions were decreased by increasing biodiesel blends in the fuel mixture, but NOx emissions were higher by increasing biodiesel blends in the fuel mixture [16].

For their study, the authors used mineral oil, gasoline, biodiesels, and various alternative fuels. When the diesel fuel exhibited improved injection timing was seen that BTE was greater with diminished fuel consumption and minimal $\mathrm{HC}$ and $\mathrm{CO}$ emissions. However, NOx emission was found to be higher. Retarded injection time resulted in a reduction in cylinder pressure, which further led to reduced peak temperature resulting in decreased NOx emission. During the retarded injection timing, the fuel injection happened slowly because of which the duration of combustion and cylinder peak pressure were lowered. Due to this reason fuel efficiency was also reduced. On the contrary, advanced injection timing enhanced 
the combustion process and the fuel efficiency was also higher. It was also found that oxidation capacity was increased with increased cylinder temperature. It further resulted in a decreased $\mathrm{O}_{2}$, carbon (C), $\mathrm{CO}$, and $\mathrm{HC}$ emissions and EGT. Normally, diesel-biodiesel fuel blends gave higher $\mathrm{HC}$ and $\mathrm{CO}$ emissions. However, in the case of retard injection timing the NOx emissions were minimized [17].

In this study, the diesel is mixed with n-octanol with various percentages of $10 \%, 20 \%$, and $30 \%$, respectively. The experiments also used EGR at a rate of $10 \%, 15 \%$, and $20 \%$ with injection timing advanced and retarded conditions. The best position of brake thermal efficiency is obtained by diesel with a blend of $10 \% \mathrm{n}$-octanol in $10 \% \mathrm{EGR}$ at $23^{\circ} \mathrm{CA}$ bTDC. There is the simultaneous reduction of smoke, NOx, and $\mathrm{CO}$ of blend diesel with $10 \%$ n-octanol $+10 \%$ EGR in advanced injection timing of $47.77 \%$, $21.08 \%$, and $18.76 \%$, respectively, due to the antioxidants agents its react as a catalyst more oxygen content available in the antioxidants proper combustion takes places and shorten ignition delay [18].

The novelty of work is clear from the above literature review that the various additives added to biodiesel led to improved efficiency and decreased harmful environmental emissions. The modification of the injection timing and the introduction of the fuel additives resulted in the diesel engine with superior output and emission characteristics. The present work was conducted with various injection timings such as $21^{\circ} \mathrm{CA}$ bTDC for retardation, $23^{\circ} \mathrm{CA}$ bTDC for standard and $25^{\circ} \mathrm{CA}$ bTDC for advanced. The mahua biodiesel is mixed with the diesel and additives, they are prepared the three blends for investigation of M100 (mahua raw oil), M20 (mahua oil 20 vol.\% + diesel 80 vol.\%) and NBM (mahua oil 20 vol.\% + diesel 80 vol. $\%+n$-butanol 30 vol.\%). These blends are used in the current investigation with varying injection timing (advancing and retardation) and then compared with mineral diesel fuel.

Table 7 shows that the comparison of various ignition timing for different fuel blends from the previous literature survey. The table uses two arrow symbols, one is upward arrows and the other one is downward arrow. The upward arrow symbol indicates increased performance and emission characteristics while the downward arrow symbol indicates decreased performance and emission characteristics.

Table 8 shows the comparison of different antioxidants used in diesel engines with different fuels. The table uses two arrow symbols, one is upward arrow and the other one is downward arrow. The upward arrow symbol indicates increased performance and emission characteristics and downward arrow symbol indicates decreased performance and emission characteristics.

\section{li. Outline Of Mahua Biodiesel}

Two types of mahua variety namely Madhuca longifolia and Madhuca indica are seen in India, especially in the dry lands and wastelands. The seeds are commonly known as Indian spread tree seeds. The specific gravity of mahua raw oil is $9.11 \%$, that is, higher than base diesel fuel. The specific gravity of mahua oil was 15.23 times more than the base fuel at $40^{\circ} \mathrm{C}$. The specific gravity of mahua oil diminished 
fundamentally with increase in temperature to $80^{\circ} \mathrm{C}$. By extending the degree of diesel in fuel blends. The seeds contain between $30 \%-40 \%$ greasy oil called mahua oil, which is attractive and is used in the production of a variety of products, for example, chemicals and glycerin. The oil cake is used as biomanure, characteristic compost, and as feed for fish and steers. The leaves are used as feed and as green manure. The blooms are used for evacuating ethanol, which is used in making country liquor. Figure 1 depicts the fatty acid concentrations of mahua biodiesel.

\section{Production of Mahua Biodiesel}

Figure 2 shows the oil extraction process of mahua oil (up to $50 \%$ oil) from mahua seeds. The seeds are first broken and flaked during the industrialized extraction, and the resultant particles are then ovencooked. At $63^{\circ} \mathrm{C}$ the cooked flakes are broken and extracted using hexane as solvent. The resulting meal of mahua oil contained less than $1 \%$ of oil. When the crops are crushed in smallholder fields, they yield an energy-dense mahua seed cake containing up to $17 \%$ oil. The natural morphology of the mahua oil plants and their seeds are the accessibility and ignition attributes like CV, cetane number, octane number, flash point, fire point, viscosity, and density. It easily mixes with base fuel. The utilization of mahua oil as a base fuel as alternative in the compression ignition engine has now increased and showed more prominent and significant results with greater population and sensational development rate. The properties of the fatty acid composition in the mahua oil are shown in Table 1.

Table 1

Fatty acid composition for mahua biodiesel

\begin{tabular}{|llll|}
\hline Fatty Acid & Structure Number & Structure Formula & Weight (\%) \\
\hline Compounds of palmitic acid & 16.2 & $\mathrm{C}_{16} \mathrm{H}_{32} \mathrm{O}_{2}$ & 24.8 \\
\hline Compounds of stearic acid & 18.4 & $\mathrm{C}_{18} \mathrm{H}_{36} \mathrm{O}_{2}$ & 22.5 \\
\hline Compounds of arachidic acid & 20.7 & $\mathrm{C}_{20} \mathrm{H}_{40} \mathrm{O}_{2}$ & 1.5 \\
\hline Compounds of oleic acid & 18.1 & $\mathrm{C}_{18} \mathrm{H}_{34} \mathrm{O}_{2}$ & 37.5 \\
\hline Compounds of linoleic acid & 18.2 & $\mathrm{C}_{18} \mathrm{H}_{32} \mathrm{O}_{2}$ & 14.3 \\
\hline
\end{tabular}

\section{lii. Preparation Of Fuels}

Figure 3 shows the fuel preparation chart for mahua biodiesel. Biodiesel is extracted from the mahua plant, using the method of transesterification. The biodiesel density and viscosity are very similar to that of base fuel. The introduction of antioxidant (n-butanol) is to eliminate the harmful gaseous emission in the base engine. About $30 \%$ of antioxidant (n-butanol) is mixed with the $20 \%$ of mahua biodiesel and $80 \%$ of base fuel by stirring. This study was conducted with various injection timings like $21^{\circ} \mathrm{CA}$ bTDC for retardation, $23^{\circ} \mathrm{CA}$ bTDC for standard, and $25^{\circ} \mathrm{CA}$ bTDC for advanced. The mahua biodiesel is mixed with diesel and additives. Three blends have been prepared for investigation, and they are M100 (mahua 
raw oil), M20 (20 vol.\% mahua oil + 80 vol.\% diesel), and NBM (20 vol.\% of mahua oil + 80 vol.\% of diesel +30 vol. $\%$ of n-butanol). The findings of the tests were compared to those obtained from petroleum diesel fuels. Table 2 depicts the properties of various fuels used in this study.

Table 2

Properties of fuels

\begin{tabular}{|llllll|}
\hline Property & Diesel & n-butanol & M20 & M100 & NBM \\
\hline Density $\mathrm{kg} / \mathrm{m}^{3}$ & 835 & 812 & 862 & 912 & 872 \\
\hline Viscosity at $40^{\circ} \mathrm{C} \mathrm{mm} / \mathrm{sec}$ & 3.1 & 3.8 & 3.6 & 4.1 & 3.7 \\
\hline Flash point ${ }^{\circ} \mathrm{C}$ & $56-58$ & $35-37$ & $59-62$ & $61-68$ & $54-58$ \\
\hline Calorific value $\mathrm{MJ} / \mathrm{kg}$ & 48 & 17 & 38 & 37 & 41 \\
\hline Oxygen (wt.\%) & 0 & 12.3 & 2.5 & 3.1 & 14.5 \\
\hline Low heating value $\mathrm{MJ} / \mathrm{kg}$ & 44.45 & 37.9 & 42.12 & 41.45 & 40.12 \\
\hline
\end{tabular}

\section{Iv. Engine Set-up}

The Table 3 below demonstrates the basic engine's specs. The experimental arrangement comprises a single-cylinder, water-cooled in DI diesel engine. It can produce $4.4 \mathrm{~kW}$ at a base engine speed of 1500 rev per min and engine is coupled with dynamometer. The engine entry side consists of an anti-pulsing drum, a fresh air heater, and a device for measuring entry temperature. The tail pipe of the base engine consists of EGT devices, a tail pipe gas analyzer, and a smoke meter. The testing equipment also comprises a different fuel estimation measuring device to measure the utilization of mahua biodiesel blends. The test rig is fitted with a 64-bit data acquisition (DAQ) framework to gain crank angle and cylinder pressure data. The parameters for the combustion are found using the data systems. The AVL 444 flue gas analyzer is utilized to assess the visibility of the smoke. In this system, the uncertainty analysis is performed. Figure 4 shows the experimental set-up. 
Table 3

Engine specification

\begin{tabular}{|ll|}
\hline Parameter & Specification \\
\hline Type of engine & Kirloskar TV-1 \\
\hline Stroke & Four \\
\hline Cylinders & Single \\
\hline Bore $(\mathrm{mm})$ & 110 \\
\hline Compression ratio & 17.50 \\
\hline Maximum engine power $(\mathrm{kW})$ & $5.20 \mathrm{~kW} / 7$ HP@1500 rpm \\
\hline Fuel type & Diesel \\
\hline Starting & Hand start \\
\hline Injection & Direct \\
\hline Coolant & Water-cooled \\
\hline Maximum engine speed & $1500 \mathrm{rpm}$ \\
\hline Engine volume & 0.661 \\
\hline
\end{tabular}

\section{Analysis}

\section{a. Uncertainty Analysis}

All measurement equipment must undergo a precision uncertainty analysis. It was sourced from a variety of manufacturers. Uncertainty inquiry was used to rectify errors that occurred as a result of environmental circumstances, worker considerations, and assessment. Normal characteristics were determined by redirecting each examination several times to ensure the accuracy of the findings. We noticed the levels of the errors and the quantities of experiments that were compatible with the empirical errors that happened throughout the analytical technique. The uncertainty analysis is summarized in Table 4. 
Table 4

Results of uncertainty analysis.

\begin{tabular}{|lll|}
\hline No. & Parameters & Systematic Errors $(\mathbf{(})$ \\
\hline 1 & Speed, rpm & \pm 1 \\
\hline 2 & Load, N & \pm 0.2 \\
\hline 4 & Time, seconds & \pm 0.1 \\
\hline 5 & Brake Power, kW & \pm 0.5 \\
\hline 6 & Pemperature, ${ }^{\circ} \mathrm{C}$ & \pm 1 \\
\hline 7 & NOx, ppm & \pm 1 \\
\hline 8 & CO, $\%^{2}$ & \pm 9 \\
\hline 9 & CO $_{2}, \%$ & \pm 0.03 \\
\hline 10 & Unburnt hydrocarbon, ppm & \pm 10 \\
\hline 11 & Smoke, HSU & \pm 1 \\
\hline
\end{tabular}

\section{b. FTIR Analysis}

At the SRM institute of technology in Chennai, Fourier transform infrared (FTIR) spectroscopy study was performed. The FTIR analysis was performed in this study using a Nicolet, ThermoScientific model IS 10 equipment. The machine's range was determined to be between 3885.85 and $467.13 \mathrm{~cm} 1$. The study of the presence and ranges of several utility bands was finished in FTIR. Calculating the utility and vibrations of biodiesel allows for an estimation of its quality and unsaturated fat methyl ester content. FTIR research may also be used to evaluate samples as small as $10 \mathrm{~m}$. The smaller sample sizes enable the identification of particles, fibers, residues, and films. The degrees of oxidation or fixation of some polymers may be determined using FTIR analysis, which is comparable to the estimation of impurities or additional chemicals. The FTIR analysis of mahua biodiesel is shown in Fig. 5 . Table 5 illustrates the results of an FTIR study of the band structure. 
Table 5

FTIR analysis of band structure

\begin{tabular}{|llll|}
\hline No & Range of the Value & Band Value & Bond Structure \\
\hline 1 & 4123.03 & $4300-3900$ & $\mathrm{HC}$ \\
\hline 2 & 3431.45 & $3900-3200$ & $\mathrm{NH}$ \\
\hline 3 & 3145.34 & $3200-2920$ & $\mathrm{NH}$ \\
\hline 4 & 2645.23 & $2920-2530$ & $\mathrm{CH}$ \\
\hline 5 & 2312.67 & $2530-2210$ & $\mathrm{CH}$ \\
\hline 6 & 2198.78 & $2210-1970$ & $\mathrm{CH}$ \\
\hline 7 & 1865.23 & $1970-1724$ & $\mathrm{OH}$ \\
\hline 8 & 1523.67 & $1724-1430$ & $\mathrm{CO}$ \\
\hline 9 & 1320.13 & $1430-1210$ & $\mathrm{CO}$ \\
\hline 10 & 989.34 & $1210-934$ & $\mathrm{CO}$ \\
\hline 11 & 778.91 & $934-710$ & $\mathrm{CBr}$ \\
\hline 12 & 487.12 & $710-420$ & $\mathrm{Cl}$ \\
\hline
\end{tabular}

\section{c. GC-MS Analysis}

The full transesterification of triglycerides into methyl ester fatty acid was investigated using a gas chromatograph-mass spectrometer (GC-MS) study and the results were shown in Fig. 6. Thermo GCMS Trace Ultra hardware and software version 6.0 were used in this study to conduct GC-MS analysis, which was combined with data acquired from the 2.0 framework. The methyl ester fatty acid exemplified the feasibility of using biodiesel as an alternative to non-renewable energy sources. In this study, $1 \mathrm{~mL}$ of biodiesel was run through a Perkin Elmer GC-MS section, and nitrogen was used as the transporter gas at a flow rate of $1.0 \mathrm{~mL} / \mathrm{min}$. The pinnacles obtained for the test were identified by the biodiesel's contrasting n-hexane standard. The GC-MS of aromatic compounds were shown in the Table 6. 
Table 6: GC-MS of aromatic compounds 


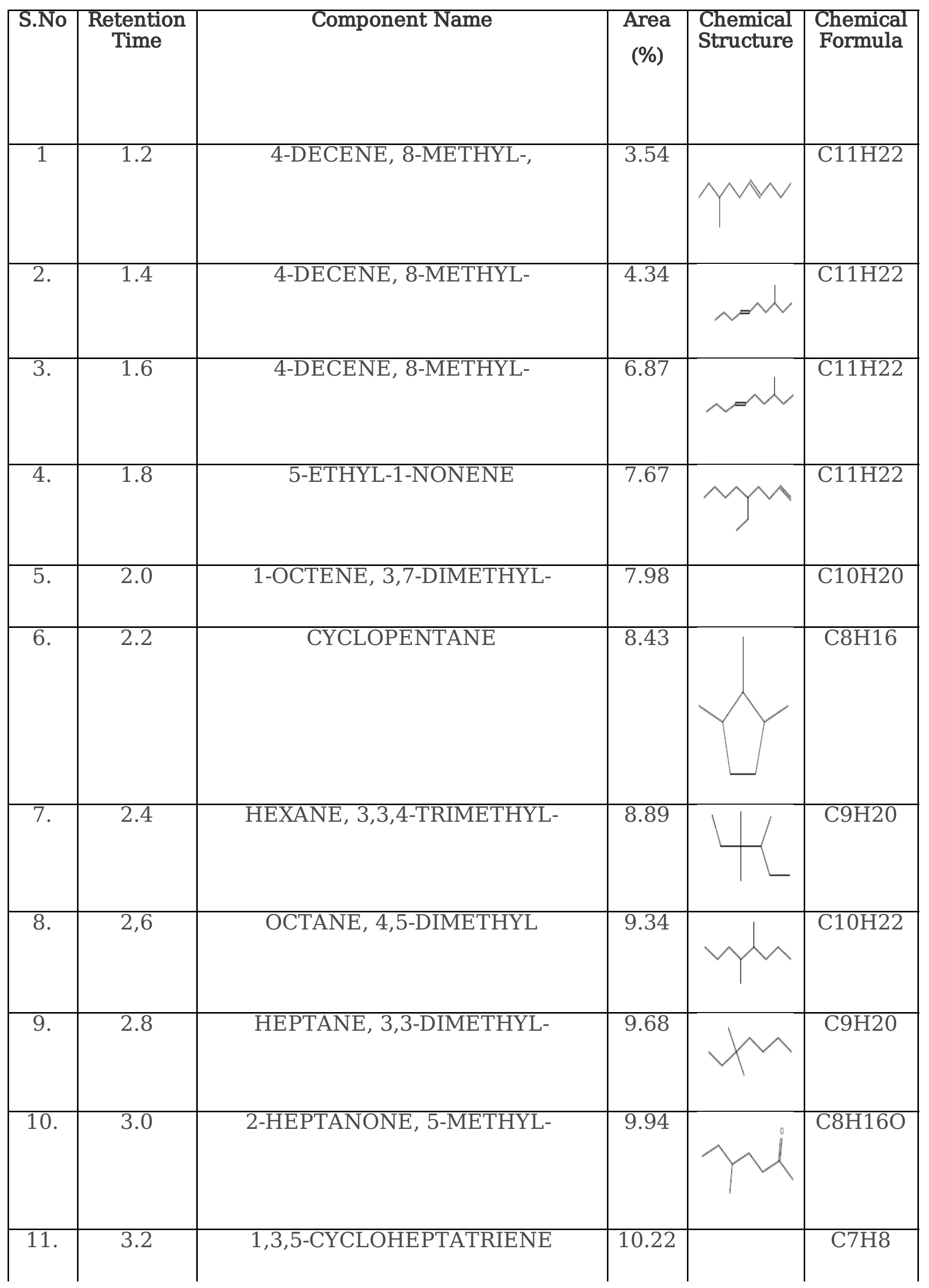




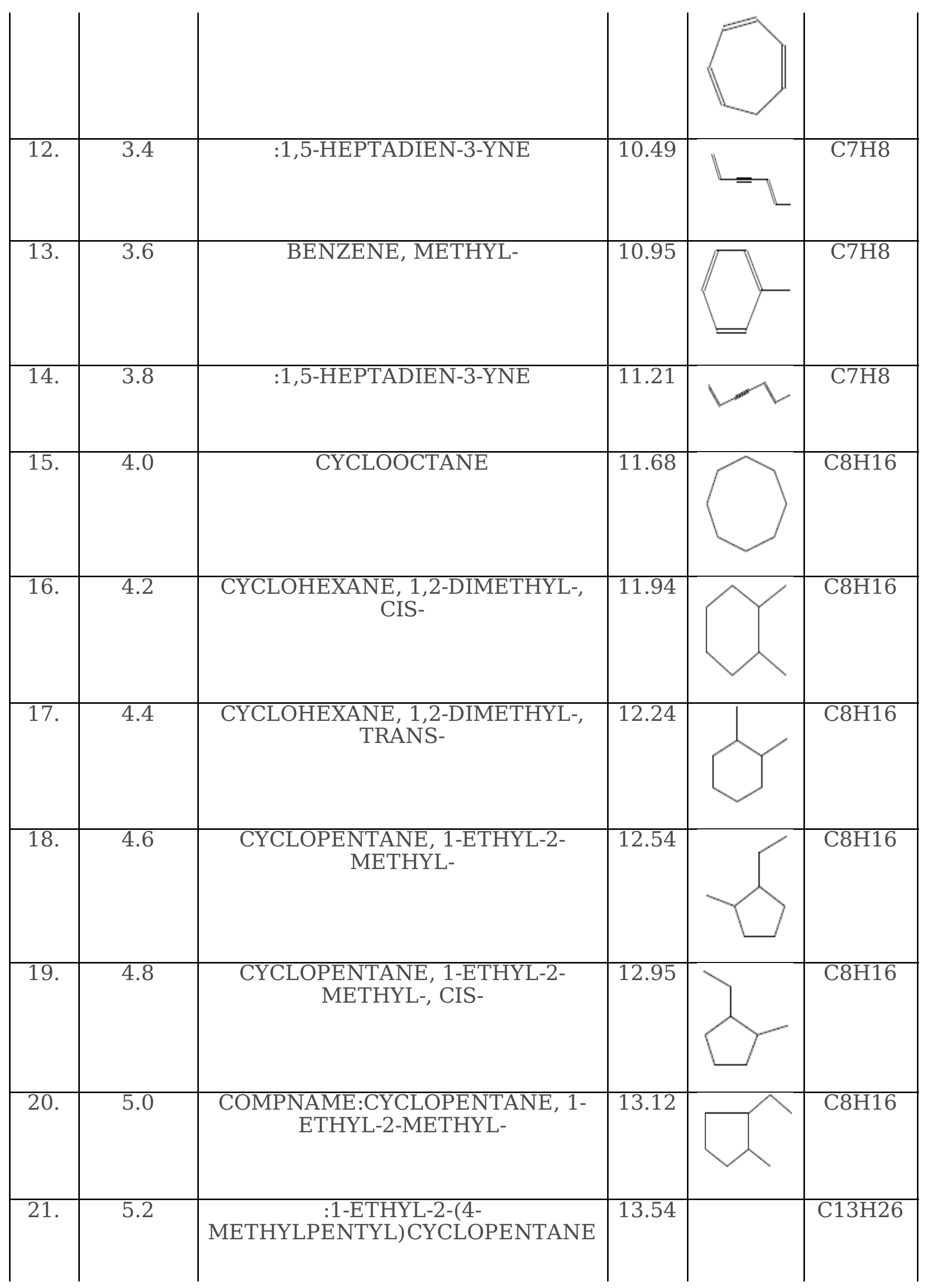

Page 14/35 


\begin{tabular}{|c|c|c|c|c|c|}
\hline 22. & 5.4 & HEXANE, 2,3,4-TRIMETHYL- & 13.97 & & $: \mathrm{C} 9 \mathrm{H} 20$ \\
\hline 23. & 5.6 & OCTANE, 4-METHYL- & 14.12 & & $\mathrm{C} 9 \mathrm{H} 20$ \\
\hline 24. & 5.8 & $\begin{array}{c}\text { CYCLOHEXANE, 1,2-DIMETHYL-, } \\
\text { CIS }\end{array}$ & 14.54 & & C8H16 \\
\hline 25. & 6.0 & $\begin{array}{c}\text { CYCLOHEXANE, } 1,2-\text { DIMETHYL-, } \\
\text { TRANS- }\end{array}$ & 14.86 & & $\mathrm{C} 8 \mathrm{H} 16$ \\
\hline 26. & 6.2 & $\begin{array}{l}\text { CYCLOHEXANE, 1,4-DIMETHYL-, } \\
\text { CIS- }\end{array}$ & 15.14 & & $\mathrm{C} 8 \mathrm{H} 16$ \\
\hline 27. & 6.4 & CYCLOHEPTANE, METHYL- & 15.42 & & $\mathrm{C} 8 \mathrm{H} 16$ \\
\hline 28. & 6.6 & HEXANE, 2,2,5-TRIMETHYL- & 15.85 & & C9H20 \\
\hline 29. & 6.8 & HEXANE, 2,2,5-TRIMETHYL & 16.12 & $M \mathbb{M}$ & $\mathrm{C} 9 \mathrm{H} 20$ \\
\hline
\end{tabular}

\section{Vi. Results And Discussion}

\section{A. Performance Characteristics}

a. $\mathrm{NO}_{\mathrm{x}}$ Emissions 
Figure 7 illustrates the variation in NOx emission of the tested fuel under full load conditions. In particular, the diesel engine produces lower nitrogen oxides at the starting load level, and it increases at full load level. Nitrogen oxides rise slowly and eventually correspond to neat base fuel owing to the enhanced oxygen availability in the fuel due to the addition of $n$-butanol antioxidants. [27].NBM showed reduced nitrogen oxides compared with pure diesel fuel, M100, and other tested fuel mixtures at part load and full load status of oxide of nitrogen producing results at 342 and 1054 ppm, respectively. It is due to the change in temperature induced by vaporization of $n$-butanol which reduced the latent heat and greater oxygen availability, which caused high peak temperature during improved combustion [28]. The NBM $23^{\circ} \mathrm{CA}$ bTDC blend showed decreased NOx content by $28.34 \%$ then correlated with the neat base fuel. The NDM $25^{\circ} \mathrm{CA}$ bTDC blend showed slightly increased emission by $5.38 \%$ when compared with the diesel fuel. The NBM $\left(21^{\circ} \mathrm{CA}\right.$ bTDC) showed a $32.17 \%$ decline in NOx emission relative to diesel fuel attributable to the anti-oxidant involvement of oxidative amine reaction preventing peroxyl-free radical formations. These peroxyl free radical formations form the focal point of higher emissions of NOx. A free radical is the oxidizing agent of molecules that determines the oxidation reaction rate [29].

\section{b. Smoke Opacity}

Figure 8 demonstrates the diversity in smoke intensity and all tested fuels concerning full load conditions. The smoke opacity emission in clean biodiesel is high as compared with all measured fuels. The mahua biodiesel had higher toxicity for smoke in previous studies. Since n-butanol antioxidants are blended with mahua biodiesel and diesel fuel, the intensity of smoke decreased, because of the ascent in fuel oxygen in the mixes and the accessibility of oxygen content even in fuel-rich regions. The smoke emission of M20 and NBM at 21 OCA bTDC is slightly decreased by $2.5 \%$ and $1.25 \%$, respectively, when correlated with neat base fuel and raw oil is increased in the smoke emission. The reason may be attributed to the higher cetane amount of diesel and the ignition delay period. The smoke opacity of NBM with injection timing 23oCA bTDC and 25oCA bTDC was seen to be decreased by $32.5 \%$ and $40 \%$, respectively, when correlated with neat pure base fuel. It produces low smoke emissions as equated with all the other high engine load fuels. The explanation for low emission is due to engine operated with optimum 25oCA bTDC injection timing, which improved the dwelling time for fuel and air blending leading to clean and assured combustion. Such combined results gradually diminish the release of smoke with respect to the timing of advance injection [30].

\section{c. CO Emissions}

Figure 9 demonstrates the emission of $\mathrm{CO}$ and all measured fuels under the full load condition. Emission of $\mathrm{CO}$ is seen throughout the working of diesel engine due to inadequate combustion produce by the unavailability of the oxygen. If the $\mathrm{CO}$ emission of the engine is increased and the n-butanol additives are added to the fuel, the low $\mathrm{CO}$ is emitted throughout the diesel engine [31]. The blend NBM (210CA bTDC) produces $29.41 \%$ (high-level of $\mathrm{CO}$ ) related to diesel fuels; this is attributable to little combustion duration and need of arrangement time in the combustion bowl. When the blend of NBM with injection timings, 230CA bTDC and 250CA bTDC is used, it is found that CO emission has been reduced by $8.6 \%$ and

Page 16/35 
$16.53 \%$, respectively, when correlated with the neat base fuel. Due to the introduction of n-butanol additives and high temperatures at high loads levels, the blend NBM (250CA bTDC) has low emission of $\mathrm{CO}(0.14 \%)$, relative to diesel fuels. Prolonged delay time boosts fuel spraying pattern and atomization and thus increased burning occurring in the container [23].

\section{d. HC Emissions}

Figure 10 demonstrates the diverse in the emission of $\mathrm{HC}$ and all the measured fuels concerning the full load condition. Considering the proximity of unsaturated $\mathrm{HC}$ which is strong during most of the combustion cycle, the $\mathrm{HC}$ emission is usually high for neat biodiesel than diesel fuel [32]. Owing to inadequate burning and lower delay time, the blend NBM $\left(21^{\circ} \mathrm{CA}\right.$ bTDC) provided $10.31 \%$ higher level of $\mathrm{HC}$ emission, when correlated with neat base fuel resulting in poor atomization. Standard diesel reports low $\mathrm{HC}$ emissions at peak load and normal timing. Compared with standard diesel fuel, the blend NBM ( $25^{\circ} \mathrm{CA}$ bTDC) offered low $\mathrm{HC}$ emission of $38.12 \%$, when correlated with the base fuel due to advanced ignition timing and quicker ignition delay[33]. It might be due to improvement in the evaporation cycle and further enhancement during the preparing of the air-fuel mixture, contributing to clean combustion eventually [34].

\section{B. Performance Characteristics}

\section{a. BTE}

The BTE variations with respect to load are shown in Figure 11 with the contradiction effect of different injection timings with M100, M20, and NBM fuel. The lower thermal efficiency of the raw mahua biodiesel was then contrasted with all other tested fuels, as mahua displayed a reduction in performance since additional energy is required to breakdown huge $\mathrm{HC}$ chain and substantial aromatic substances affecting mahua biodiesel [35]. Compared with all other measured fuels, the brake thermal performance was increased by including the additives in the fuels. It is associated to retarding the timing of fuel injection in the engine at 210CA bTDC, 230CA bTDC, and 250CA bTDC. There was an inadequate period for air-fuel blending to delay the fuel injection and inadequate combustion was noted [36]. The increase in BTE of NBM with injection timings, 210 CA bTDC, 230CA bTDC, and 250CA bTDC were found to be improved by $3.53 \%, 10.12 \%$, and $15.56 \%$ then correlated with neat base fuel. That was due to the ample residence time in the cylinder for preparing the air-fuel mixture with a longer combustion period [37].

\section{b. Brake Specific Energy Consumption}

Figure 12 illustrates the pattern for the brake specific energy consumption (BSEC) variance with load for different injection timings and with M100, M20, and NBM $\left(21^{\circ} \mathrm{CA}\right.$ bTDC) fuels. The calorific value plays a significant part in this investigation. Generic diesel fuel at standard $23^{\circ} \mathrm{CA}$ bTDC injection time demonstrated low BSEC on a par with all other fuels [38]. This can be ascribed as equated with all other fuels to a higher fuel heating benefit. NBM $\left(21^{\circ} \mathrm{CA}\right.$ bTDC) has higher BSEC levels. It is due to the retarded injection pressure of fuel at $21^{\circ} \mathrm{CA}$ bTDC. Although the retardation cycle had a greater combustion 
temperature and higher pressure, it does not have enough time for full burning [26]. Therefore the more quantity of fuel was consumed during most of the retardation cycle. The NBM (250CA bTDC) has fewer BSEC compared with NBM (210CA bTDC) and NBM (230CA bTDC). It is due to the efficient use of fuel by keeping the cycle of burning very close to fuel, which would increase the evaporation in the tank, hence lower BSEC was observed [39].

\section{Combustion Characteristics}

\section{a. Cylinder Pressure}

Deviations between the cylinder pressures are based on various crank angles for NBM, M100, and M20 fuels followed by diesel fuel at NBM $23^{\circ} \mathrm{CA}$ bTDC, NBM $21^{\circ} \mathrm{CA}$ bTDC, and NBM $23^{\circ} \mathrm{CA}$ bTDC have been shown in Figure 13 respectively. Relative to all other fuels, the NBM $21^{\circ} \mathrm{CA}$ bTDC showed low combustion pressure peaks.

dQ_c $=d u+w+d Q \_h$

(dQ_c)/dt=P dv/dt+mc_v dT/dt+(dQ_h)/dt

$\left(\mathrm{dQ} \_\mathrm{C}\right) / \mathrm{dt}=\mathrm{P} \mathrm{dv} / \mathrm{dt}+\mathrm{mc} \_\mathrm{v} \mathrm{d} / \mathrm{dt} \quad[\mathrm{PV} / \mathrm{mR}]$

(dQ_c)/dt=P dv/dt+c_v/R d/dt [P dv/dt+V dp/dt]

$\mathrm{C} \_\mathrm{v} / \mathrm{R}=1 /(\mathrm{\gamma}-1)$

$\left(d Q \_C\right) / d t=\gamma /(\gamma-1) P d v / d t+1 /(\gamma-1) V d p / d t$

The factors for the low cylinder pressure are due to poor atomization and less time of preparation at lower injection timing levels. At NBM $25^{\circ} \mathrm{CA}$ bTDC fuel gives inflated cylinder pressure on par with all the injection timings and fuels [40]. It is because of enhanced air-to-fuel mixing, evaporation rate and ignition delay due to $25^{\circ} \mathrm{CA}$ bTDC IT. The diesel fuel at $23^{\circ} \mathrm{CA}$ bTDC slightly increases the cylinder pressure when compared with NBM at $21^{\circ} \mathrm{CA}$ bTDC. Due to variations in injection timing and properties, such as heating value and cetane number, the pressure was found to increase. To conclude, NBM $25^{\circ} \mathrm{CA}$ bTDC can be recommended for the diesel engine powered by NBM [41].

\section{Vii. Conclusions}

The experimental investigation attempted a novel approach of using mahua biodiesel with n-butanol antioxidant fuel in DI diesel engine. The following are the inferences of the experiments:

NBM $\left(21^{\circ} \mathrm{CA}\right.$ bTDC) showed an appreciable reduction (32.17\%) of NOx, when correlated with neat base fuel. The reaction with aromatic amines effectively stopped the formation of peroxyl free radicals. 
The smoke emissions were reduced by $15.56 \%$ when the blends NBM $25^{\circ} \mathrm{CA}$ bTDC were used when correlated to neat fuel at full load conditions. Because of oxygen availability in the fuel, decrease in dwelling time during the combustion process is possible.

The $\mathrm{CO}$ emission was found to be decreased by $8.6 \%$ and $16.53 \%$ when NBM with injection timings ${ }^{2} 3^{\circ} \mathrm{CA}$ bTDC and $25^{\circ} \mathrm{CA}$ bTDC, this is because of the effect of antioxidants and shorten ignition delay.

A significant reduction of hydrocarbons was observed when NBM blends at $25^{\circ} \mathrm{CA}$ bTDC when correlated to neat base fuel, because of the improvement in the evaporation cycle and more oxygen content available in the fuel.

A remarkable increase in BTE has been found when NBM was used as fuel with injection timings $21^{\circ} \mathrm{CA}$ bTDC, $23^{\circ} \mathrm{CA}$ bTDC, and $25^{\circ} \mathrm{CA}$ bTDC. The increase was found to be more by $3.53 \%, 10.12 \%$, and $15.56 \%$, respectively, when compared with neat diesel fuel.

NBM at $25^{\circ} \mathrm{CA}$ bTDC gave inflated in-cylinder pressure, which is on par with standard injection timing with other fuels, which is because of enchanted air-fuel mixing, evaporation rate, and ID.

As a concluding remark, the tremendous reduction in emission parameters which is vital for the current scenario with the beneficial increase in BTE proves NBM with antioxidants to be a promising alternative fuel source for a diesel engine without any modification.

Table 9 shows the comparison results for different injection timing performance and emission characteristics. In the table shows two arrow symbols, one is upward arrow and the other one is downward arrow. The upward arrow symbols show increase in injection timing performance and emission characteristics and the downward arrow symbols show decrease in injection timing performance and emission characteristics. Figure 14 shows the graphical picture of the comparison results.

\section{Declarations}

\section{Permissions}

The authors have authorization to gather Madhuca longifolia and Madhuca indica. We have all permits and we certify handlings of plants were carried out in compliance with applicable rules and laws.

\section{Viii. References}

1. Reşitoğlu, I.A., Keskin, A.: Biodiesel production from free fatty acids and the effects of its blends with alcohol-diesel on engine characteristics. Clean Techn Environ Policy. 19, 3, 925-931 (2016). https://doi.org/10.1007/s10098-016-1255-3. 
2. Datta, A., Mandal, B.K.: An experimental investigation on the performance, combustion and emission characteristics of a variable compression ratio diesel engine using diesel and palm stearin methyl ester. Clean Techn Environ Policy. 19, 5, 1297-1312 (2017). https://doi.org/10.1007/s10098-0161328-3.

3. Datta, A., Mandal, B.K.: A numerical study on the performance, combustion and emission parameters of a compression ignition engine fuelled with diesel, palm stearin biodiesel and alcohol blends. Clean Techn Environ Policy. 19, 1, 157-173 (2016). https://doi.org/10.1007/s10098-016-1202-3.

4. LChuah, L.F. et al.: Performance and emission of diesel engine fuelled by waste cooking oil methyl ester derived from palm olein using hydrodynamic cavitation. Clean Techn Environ Policy. 17, 8, 2229-2241 (2015). https://doi.org/10.1007/s10098-015-0957-2.

5. Rajesh Kumar B, Saravanan S. Effect of exhaust gas recirculation (EGR) on performance and emissions of a constant speed DI diesel engine fueled with pentanol/diesel blends. Fuel 160 (2015): 217-226, http://dx.doi.org/10.1016/j.fuel.2015.07.089.

6. Shrigiri, B.M. et al.: Performance, emission and combustion characteristics of a semi-adiabatic diesel engine using cotton seed and neem kernel oil methyl esters. Alexandria Engineering Journal. 55, 1 , 699-706 (2016). https://doi.org/10.1016/j.aej.2015.12.023.

7. Sanjid, A. et al.: Production of palm and jatropha based biodiesel and investigation of palm-jatropha combined blend properties, performance, exhaust emission and noise in an unmodified diesel engine. Journal of Cleaner Production. 65, 295-303 (2014).

https://doi.org/10.1016/j.jclepro.2013.09.026.

8. Reza Miri, S.M. et al.: Effects of biodiesel fuel synthesized from non-edible rapeseed oil on performance and emission variables of diesel engines. Journal of Cleaner Production. 142, 37983808 (2017). https://doi.org/10.1016/j.jclepro.2016.10.082.

9. Saravanan, A. et al.: Performance and emission characteristics of variable compression ratio $\mathrm{Cl}$ engine fueled with dual biodiesel blends of Rapeseed and Mahua. Fuel. 263, 116751 (2020). https://doi.org/10.1016/j.fuel.2019.116751.

10. Elkelawy, M. et al.: Experimental studies on the biodiesel production parameters optimization of sunflower and soybean oil mixture and DI engine combustion, performance, and emission analysis fueled with diesel/biodiesel blends. Fuel. 255, 115791 (2019). https://doi.org/10.1016/j.fuel.2019.115791.

11. Ashok, B. et al.: Experimental studies on the effect of metal oxide and antioxidant additives with Calophyllum Inophyllum Methyl ester in compression ignition engine. Journal of Cleaner Production. 166, 474-484 (2017). https://doi.org/10.1016/j.jclepro.2017.08.050..

12. Nayak, S.K., Pattanaik, B.P.: Experimental Investigation on Performance and Emission Characteristics of a Diesel Engine Fuelled with Mahua Biodiesel Using Additive. Energy Procedia. 54, 569-579 (2014). https://doi.org/10.1016/j.egypro.2014.07.298.

13. Rizwanul Fattah, I.M. et al.: Synthetic phenolic antioxidants to biodiesel: path toward NOx reduction of an unmodified indirect injection diesel engine. Journal of Cleaner Production. 79, 82-90 (2014). 
https://doi.org/10.1016/j.jclepro.2014.05.071.

14. Rajendran, S.: Effect of antioxidant additives on oxides of nitrogen (NOx) emission reduction from Annona biodiesel operated diesel engine. Renewable Energy. 148, 1321-1326 (2020). https://doi.org/10.1016/j.renene.2019.10.104.

15. Karthic, S.V. et al.: An assessment on injection pressure and timing to reduce emissions on diesel engine powered by renewable fuel. Journal of Cleaner Production. 255, 120186 (2020). https://doi.org/10.1016/j.jclepro.2020.120186.

16. Varuvel, E.G. et al.: Experimental analysis of fuel from fish processing industry waste in a diesel engine. Clean Techn Environ Policy. 19, 4, 1099-1108 (2016). https://doi.org/10.1007/s10098-0161303-z.

17. Rahman, S.M.A. et al.: Effect of idling on fuel consumption and emissions of a diesel engine fueled by Jatropha biodiesel blends. Journal of Cleaner Production. 69, 208-215 (2014). https://doi.org/10.1016/j.jclepro.2014.01.048.

18. Gopal, K. et al.: Prediction of emissions and performance of a diesel engine fueled with $\mathrm{n}$ octanol/diesel blends using response surface methodology. Journal of Cleaner Production. 184, 423-439 (2018). https://doi.org/10.1016/j.jclepro.2018.02.204.

19. Rajesh Kumar, B., Saravanan, S.: Effects of iso-butanol/diesel and n-pentanol/diesel blends on performance and emissions of a DI diesel engine under premixed LTC (low temperature combustion) mode. Fuel. 170, 49-59 (2016). https://doi.org/10.1016/j.fuel.2015.12.029.

20. Chen, Z. et al.: Study on performance and emissions of a passenger-car diesel engine fueled with butanol-diesel blends. Energy. 55, 638-646 (2013). https://doi.org/10.1016/j.energy.2013.03.054.

21. Li, L. et al.: Combustion and emissions of compression ignition in a direct injection diesel engine fueled with pentanol. Energy. 80, 575-581 (2015). https://doi.org/10.1016/j.energy.2014.12.013..

22. Choi B, Jiang X, Kim YK, Jung G, Lee C, Choi I, Song CS. Effect of diesel fuel blend with n-butanol on the emission of a turbocharged common rail direct injection diesel engine. Appl. Energy 146 (2015): 20-28. http://dx.doi.org/10.1016/j.apenergy.2015.02.061〉

23. Li, L. et al.: Combustion and emission characteristics of diesel engine fueled with diesel/biodiesel/pentanol fuel blends. Fuel. 156, 211-218 (2015). https://doi.org/10.1016/j.fuel.2015.04.048..

24. Machado, H.B. et al.: A selection platform for carbon chain elongation using the CoA-dependent pathway to produce linear higher alcohols. Metabolic Engineering. 14, 5, 504-511 (2012). https://doi.org/10.1016/j.ymben.2012.07.002.

25. Verser DW. Method for the indirect production of butanol and hexanol. US Patent 8252567 B2, Assignee to ZeeChem Inc., Menlo Park, CA (2012).

26. Yao, M. et al.: Experimental study of $n$-butanol additive and multi-injection on HD diesel engine performance and emissions. Fuel. 89, 9, 2191-2201 (2010). https://doi.org/10.1016/j.fuel.2010.04.008.. 
27. Doğan, O.: The influence of $n$-butanol/diesel fuel blends utilization on a small diesel engine performance and emissions. Fuel. 90, 7, 2467-2472 (2011).

https://doi.org/10.1016/j.fuel.2011.02.033..

28. Karabektas, M., Hosoz, M.: Performance and emission characteristics of a diesel engine using isobutanol-diesel fuel blends. Renewable Energy. 34, 6, 1554-1559 (2009). https://doi.org/10.1016/j.renene.2008.11.003..

29. Singh, Y. et al.: Optimization of performance and emission parameters of direct injection diesel engine fuelled with pongamia methyl esters-response surface methodology approach. Industrial Crops and Products. 126, 218-226 (2018). https://doi.org/10.1016/j.indcrop.2018.10.035.

30. Leite, D. et al.: Emissions and performance of a diesel engine affected by soybean, linseed, and crambe biodiesel. Industrial Crops and Products. 130, 267-272 (2019). https://doi.org/10.1016/j.indcrop.2018.12.092.

31. Miers, S.A. et al.: Drive Cycle Analysis of Butanol/Diesel Blends in a Light-Duty Vehicle. In: SAE Technical Paper Series. SAE International (2008). https://doi.org/10.4271/2008-01-2381.

32. Rakopoulos, D.C. et al.: Effects of butanol-diesel fuel blends on the performance and emissions of a high-speed DI diesel engine. Energy Conversion and Management. 51, 10, 1989-1997 (2010). https://doi.org/10.1016/j.enconman.2010.02.032.

33. Kshirsagar, C.M., Anand, R.: Artificial neural network applied forecast on a parametric study of Calophyllum inophyllum methyl ester-diesel engine out responses. Applied Energy. 189, 555-567 (2017). https://doi.org/10.1016/j.apenergy.2016.12.045.

34. Ghaziaskar, H.S., Xu, C. (Charles): One-step continuous process for the production of 1-butanol and 1hexanol by catalytic conversion of bio-ethanol at its sub-/supercritical state. RSC Adv. 3, 13, 4271 (2013). https://doi.org/10.1039/c3ra00134b..

35. Saravanan, A. et al.: Performance and emission characteristics of variable compression ratio $\mathrm{Cl}$ engine fueled with dual biodiesel blends of Rapeseed and Mahua. Fuel. 263, 116751 (2020). https://doi.org/10.1016/j.fuel.2019.116751.

36. Valentino, G. et al.: Experimental study on performance and emissions of a high speed diesel engine fuelled with n-butanol diesel blends under premixed low temperature combustion. Fuel. 92, 1, 295307 (2012). https://doi.org/10.1016/j.fuel.2011.07.035.

37. Phillips, J.R. et al.: Butanol and hexanol production in Clostridium carboxidivorans syngas fermentation: Medium development and culture techniques. Bioresource Technology. 190, 114-121 (2015). https://doi.org/10.1016/j.biortech.2015.04.043..

38. No, S.-Y.: Application of Liquid Biofuels to Internal Combustion Engines. Springer Singapore (2019). https://doi.org/10.1007/978-981-13-6737-3.

39. Sharma, A. et al.: Sustainability of jojoba biodiesel/diesel blends for DI diesel engine applicationstaguchi and response surface methodology concept. Industrial Crops and Products. 139, 111587 (2019). https://doi.org/10.1016/j.indcrop.2019.111587. 
40. Musthafa, M.M.: A comparative study on coated and uncoated diesel engine performance and emissions running on dual fuel (LPG - biodiesel) with and without additive. Industrial Crops and Products. 128, 194-198 (2019). https://doi.org/10.1016/j.indcrop.2018.11.012.

41. Zhang, K. et al.: Expanding metabolism for biosynthesis of nonnatural alcohols. Proceedings of the National Academy of Sciences. 105, 52, 20653-20658 (2008). https://doi.org/10.1073/pnas.0807157106.

\section{Supplementary}

Due to technical limitations, Table 7, 8 and 9 are only available as a download in the Supplemental Files section.

\section{Figures}

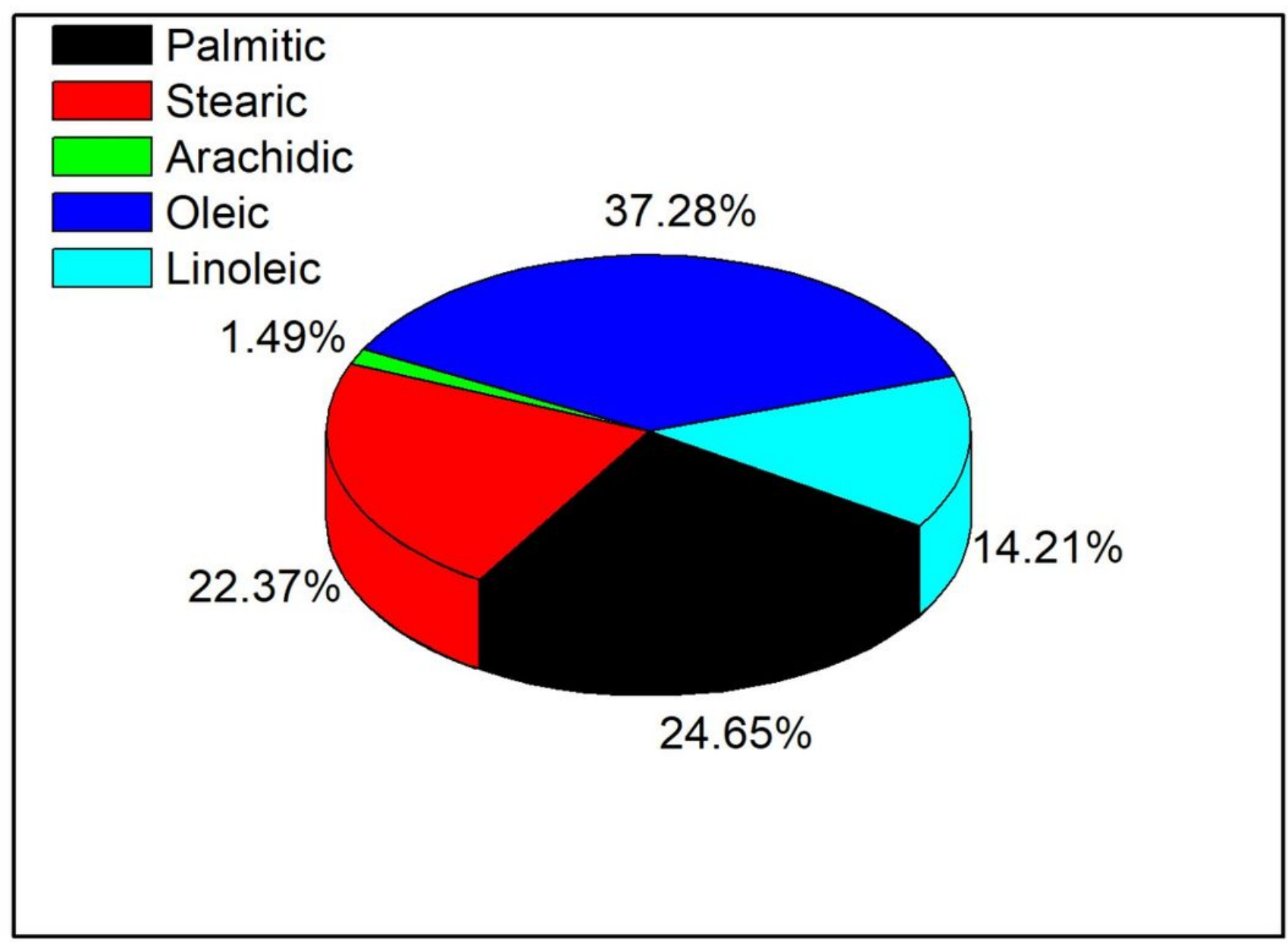

Figure 1 
Fatty acid composition

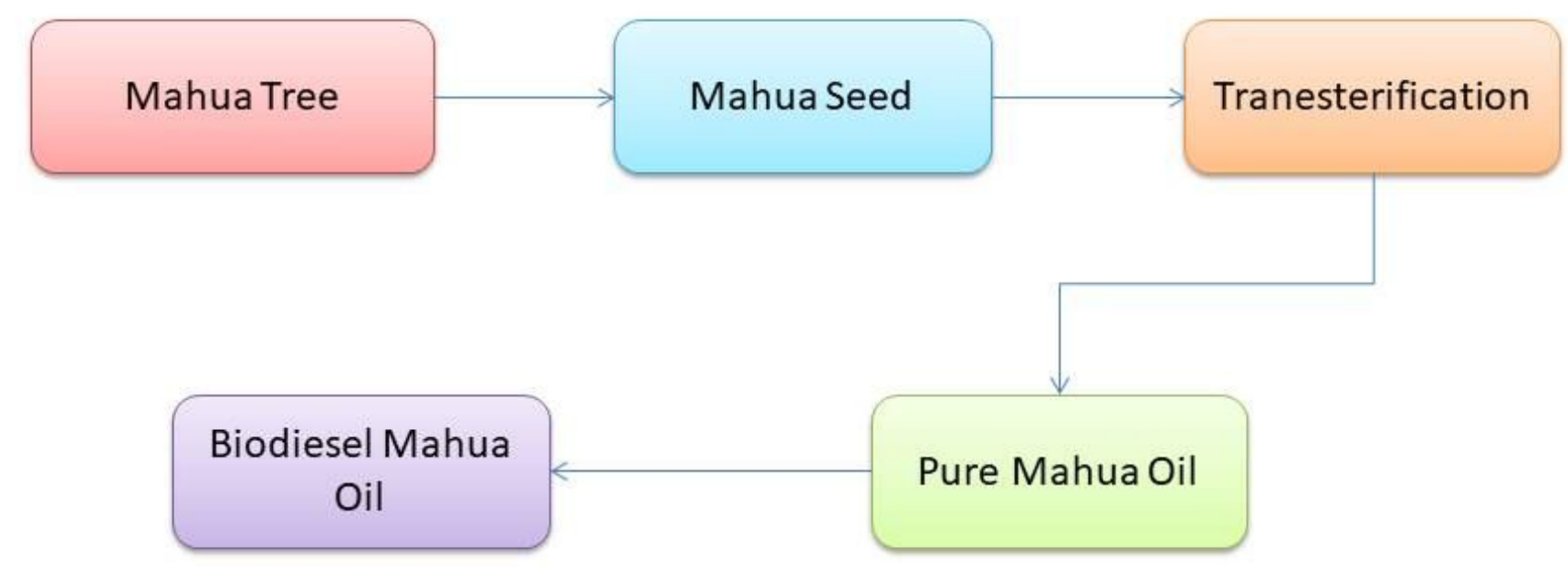

Figure 2

Oil extraction process

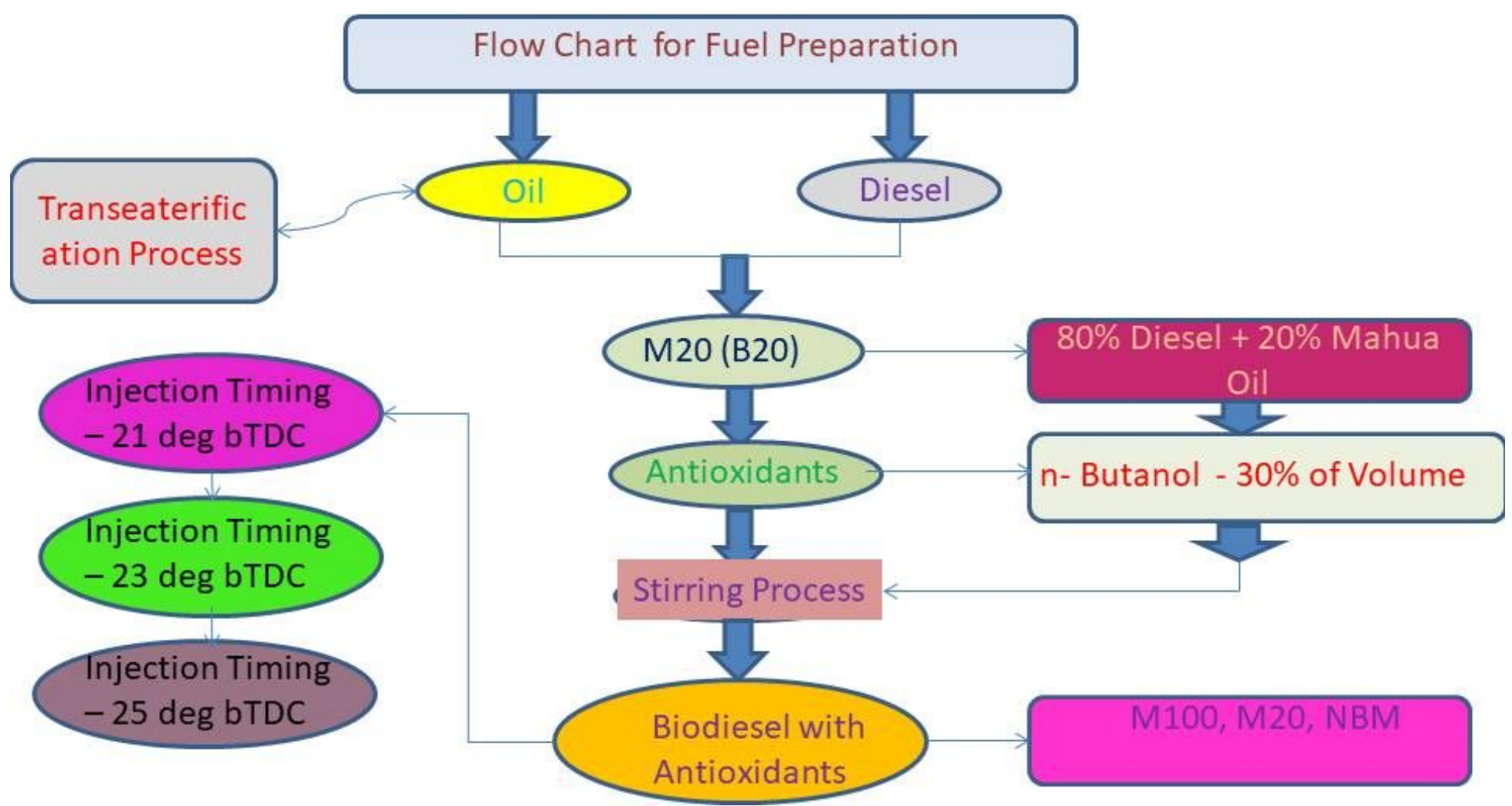




\section{Figure 3}

Fuel chart depicting preparation of mahua seed fuel

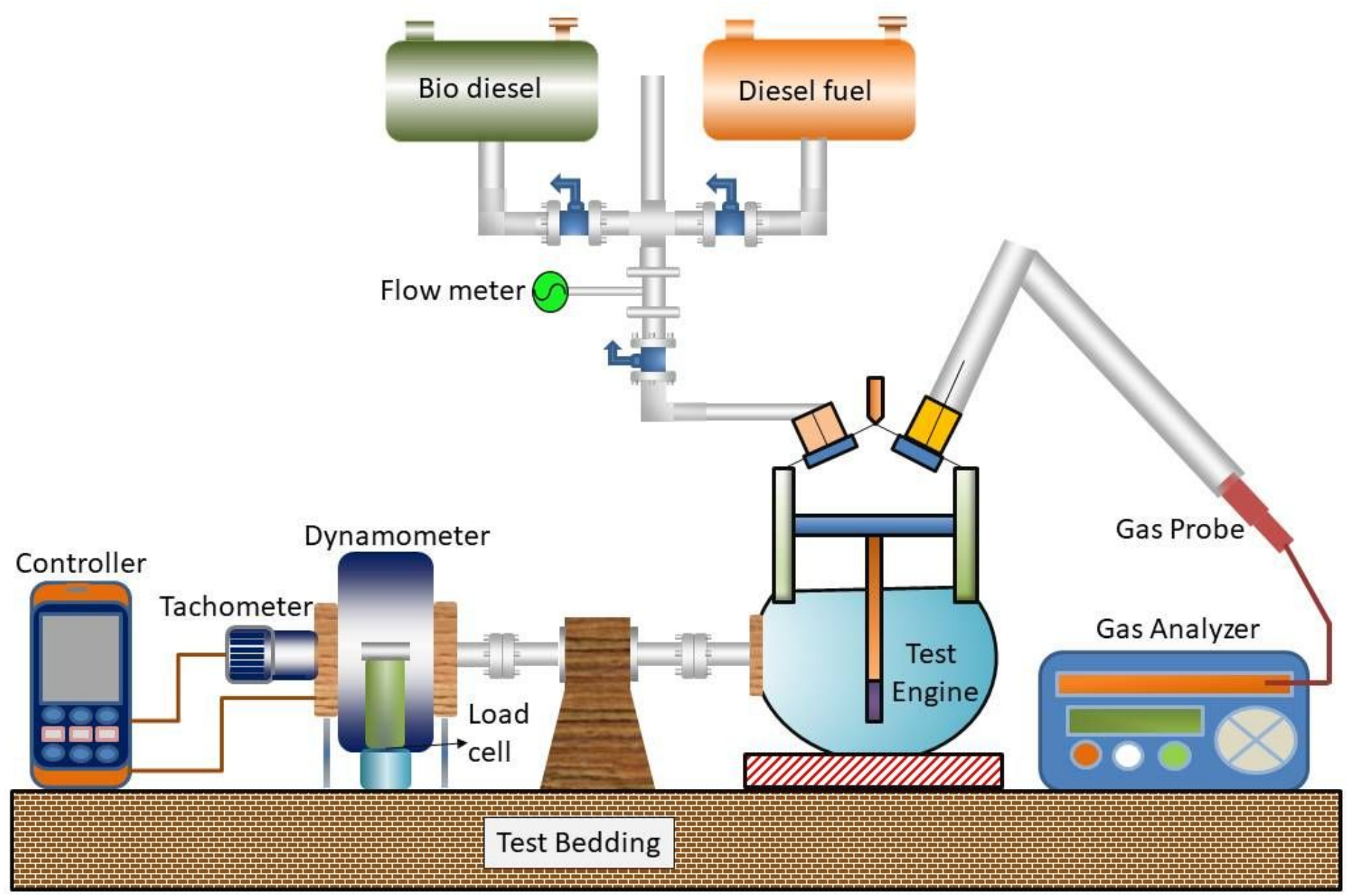

Figure 4

Engine set-up 


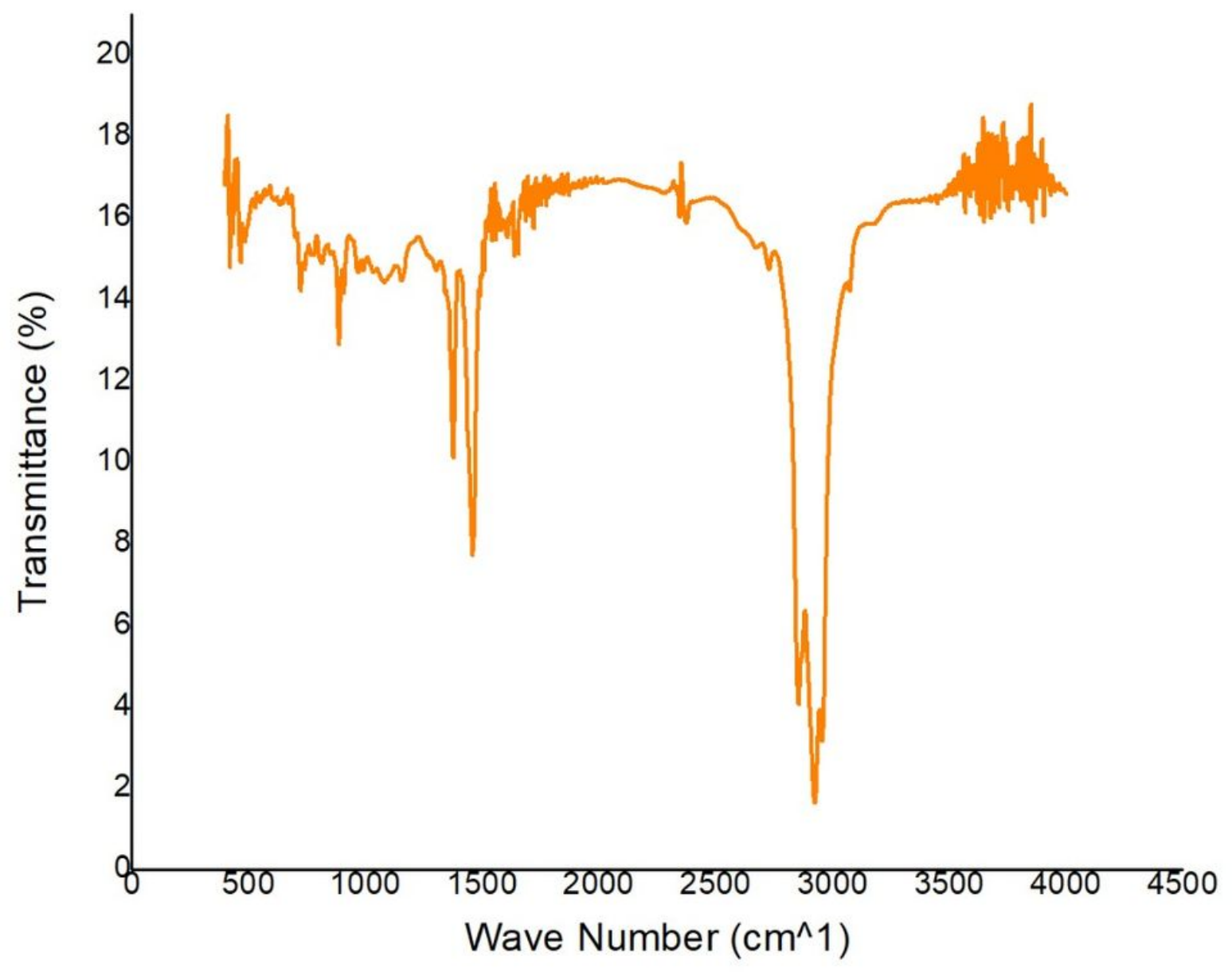

Figure 5

FTIR Analysis of Mahua Biodiesel 


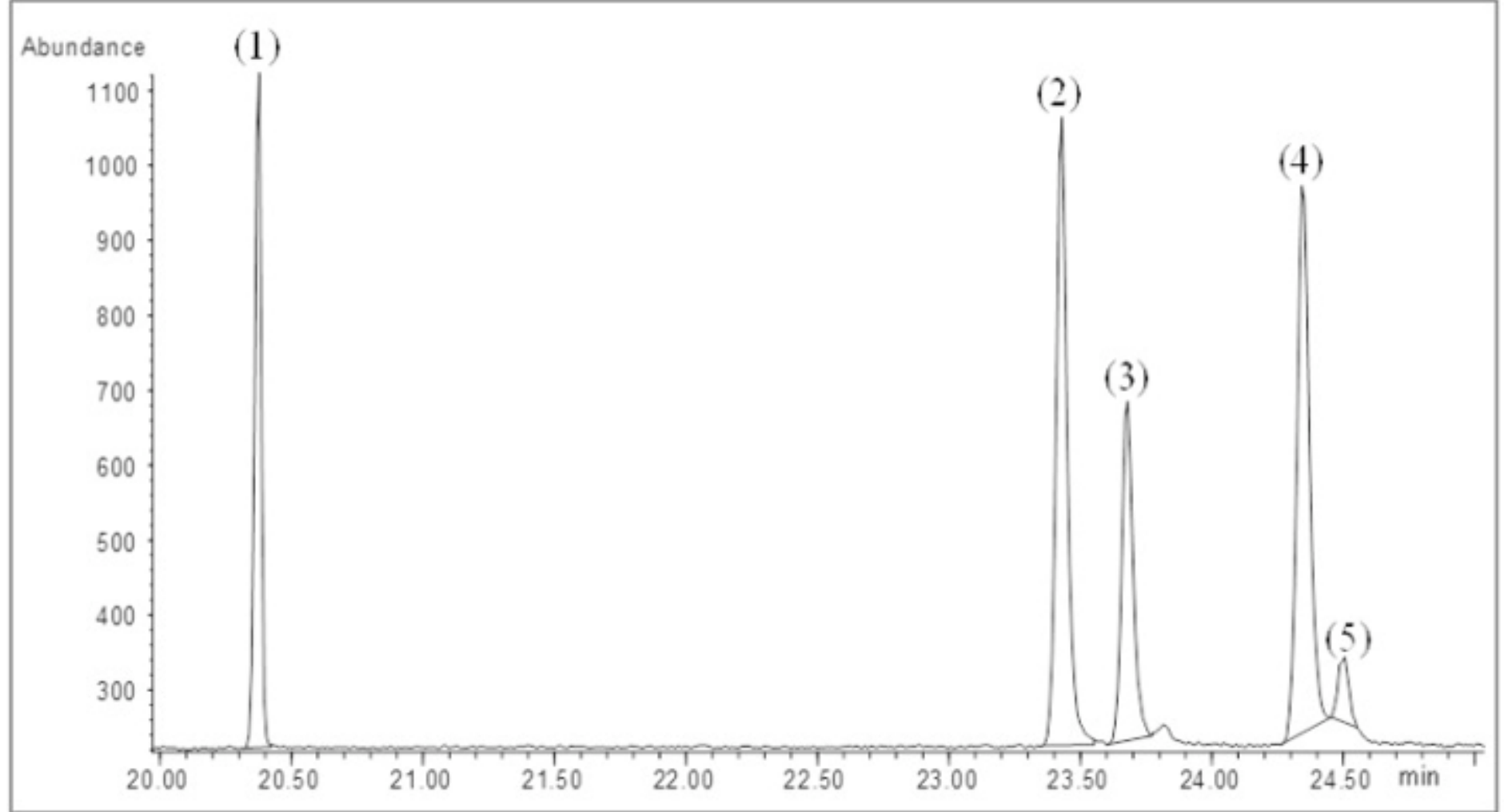

Figure 6

GC-MS of mahua biodiesel 


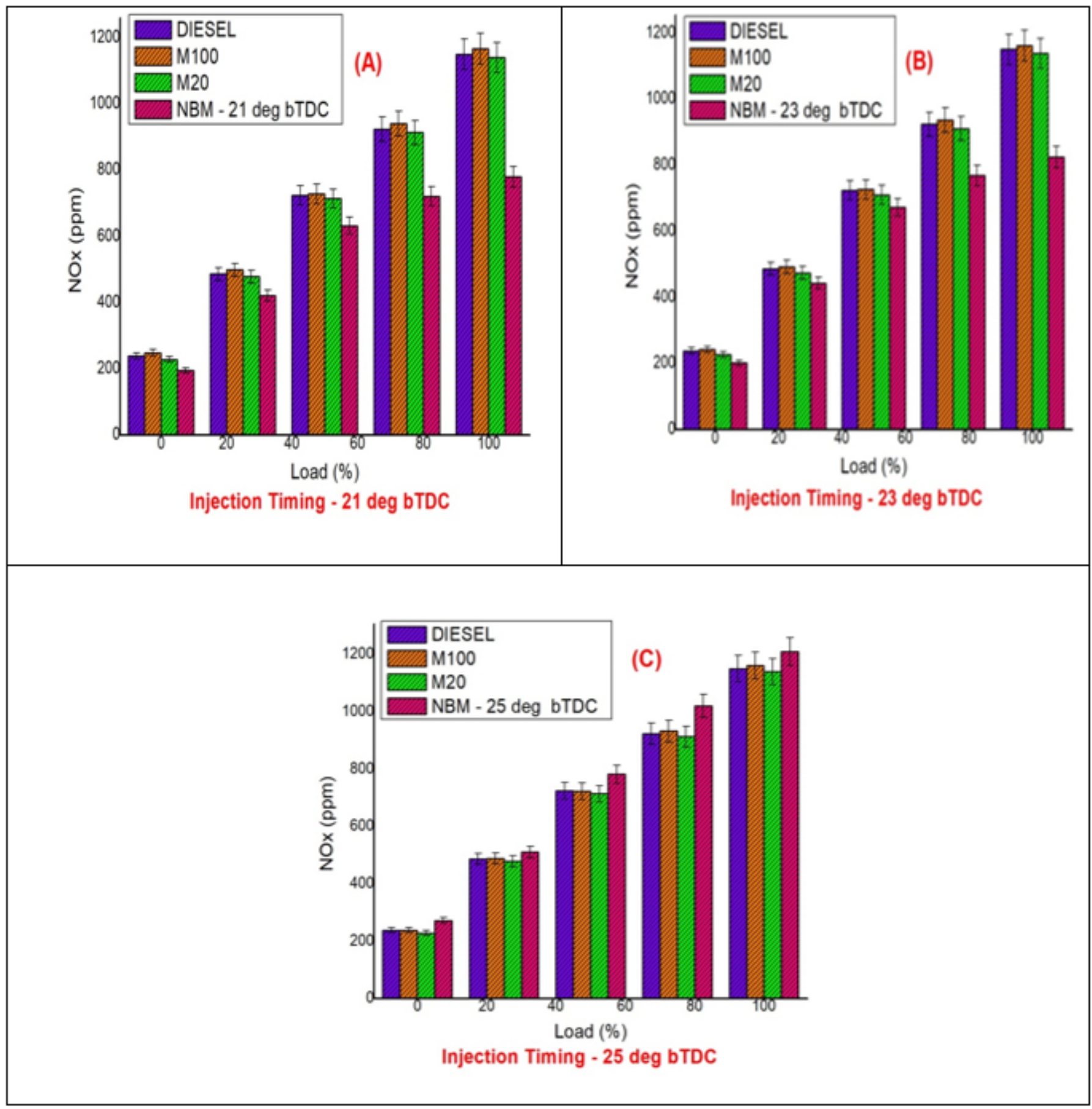

Figure 7

Variation of load vs. NOx at various blends (a) $21^{\circ} \mathrm{CA}$ bTDC, (b) $23^{\circ} \mathrm{CA}$ bTDC, and (c) $25^{\circ} \mathrm{CA}$ bTDC 


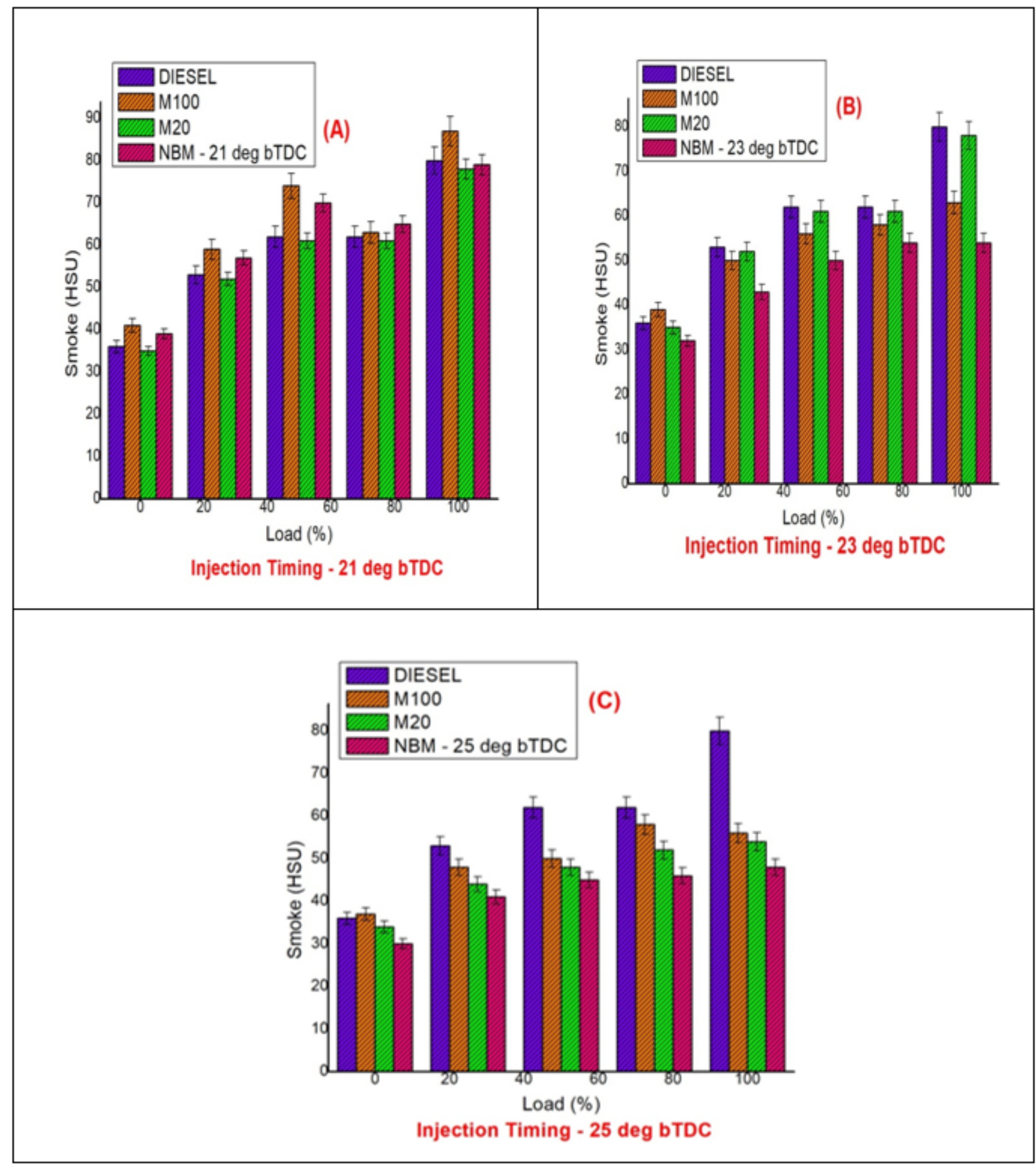

Figure 8

Variation of load vs. smoke opacity at various blends (a) $21^{\circ} \mathrm{CA}$ bTDC, (b) $23^{\circ} \mathrm{CA}$ bTDC, and (c) $25^{\circ} \mathrm{CA}$ bTDC 


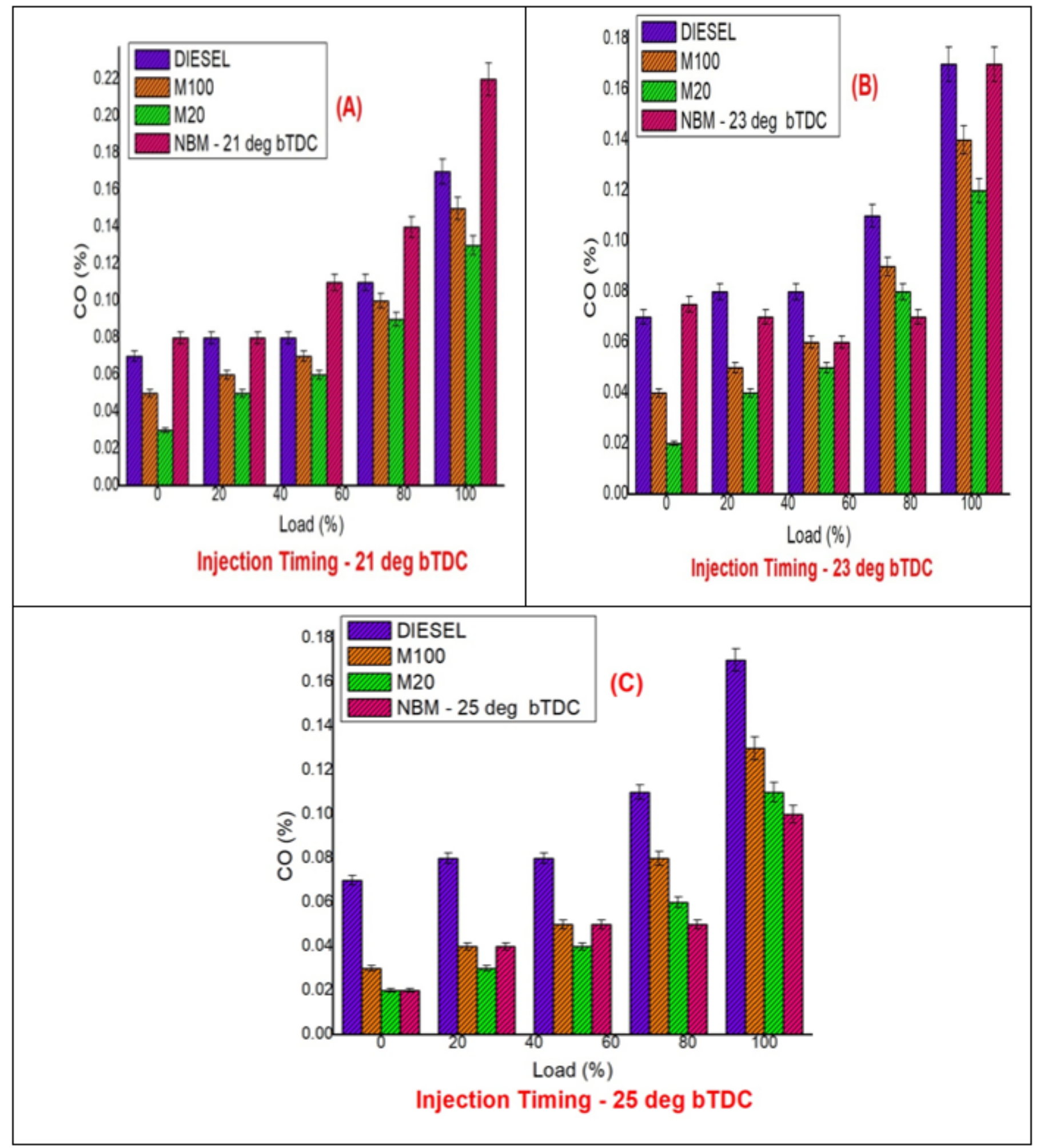

Figure 9

Variation of load vs. carbon monoxide at various blends (a) $21^{\circ} \mathrm{CA}$ bTDC, (b) $23^{\circ} \mathrm{CA}$ bTDC, and (c) $25^{\circ} \mathrm{CA}$ bTDC 


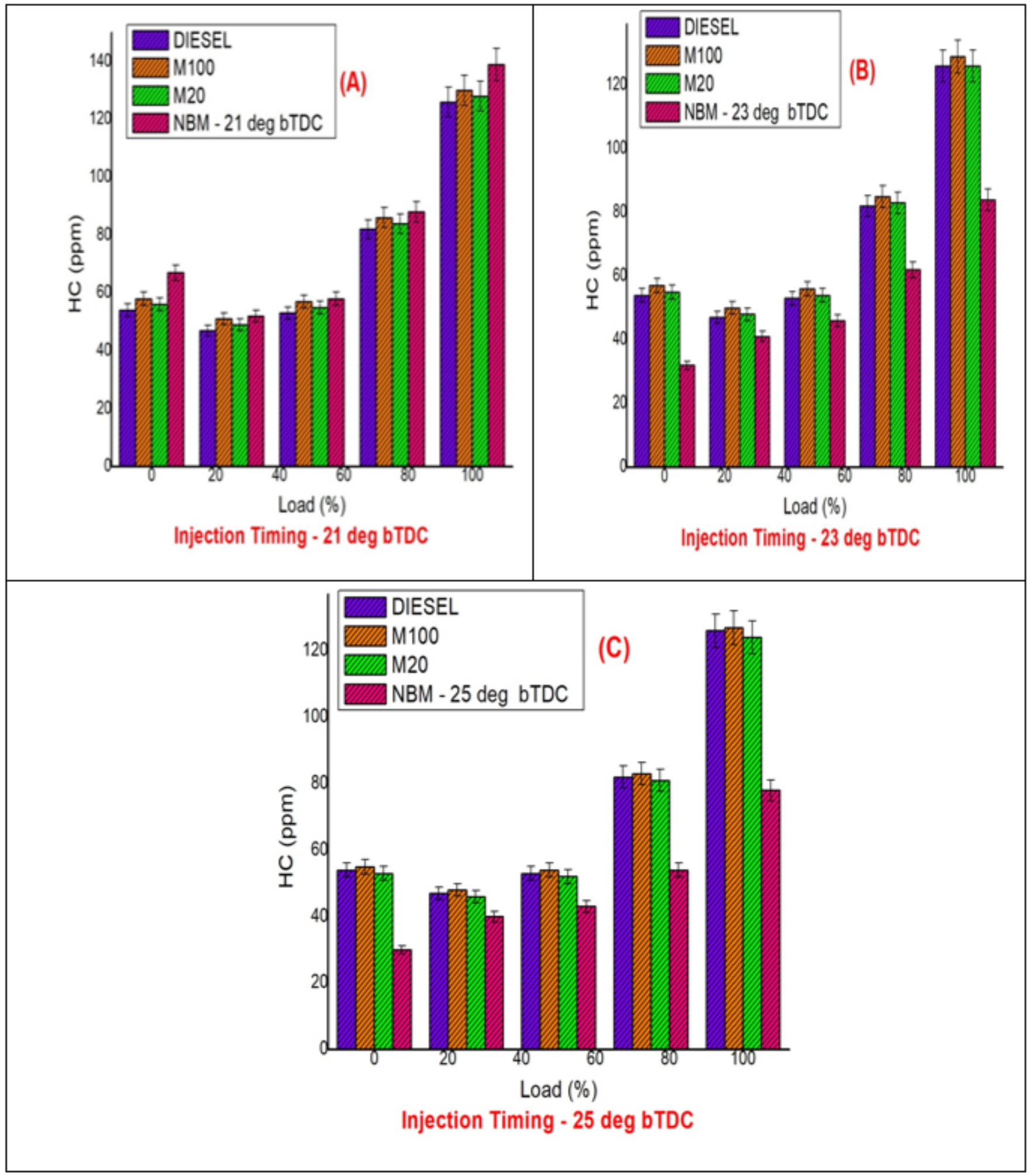

Figure 10

Variation of load vs. hydrocarbon at various blends (a) $21^{\circ} \mathrm{CA} \mathrm{bTDC,} \mathrm{(b)} 23^{\circ} \mathrm{CA}$ bTDC, and (c) $25^{\circ} \mathrm{CA}$ bTDC 


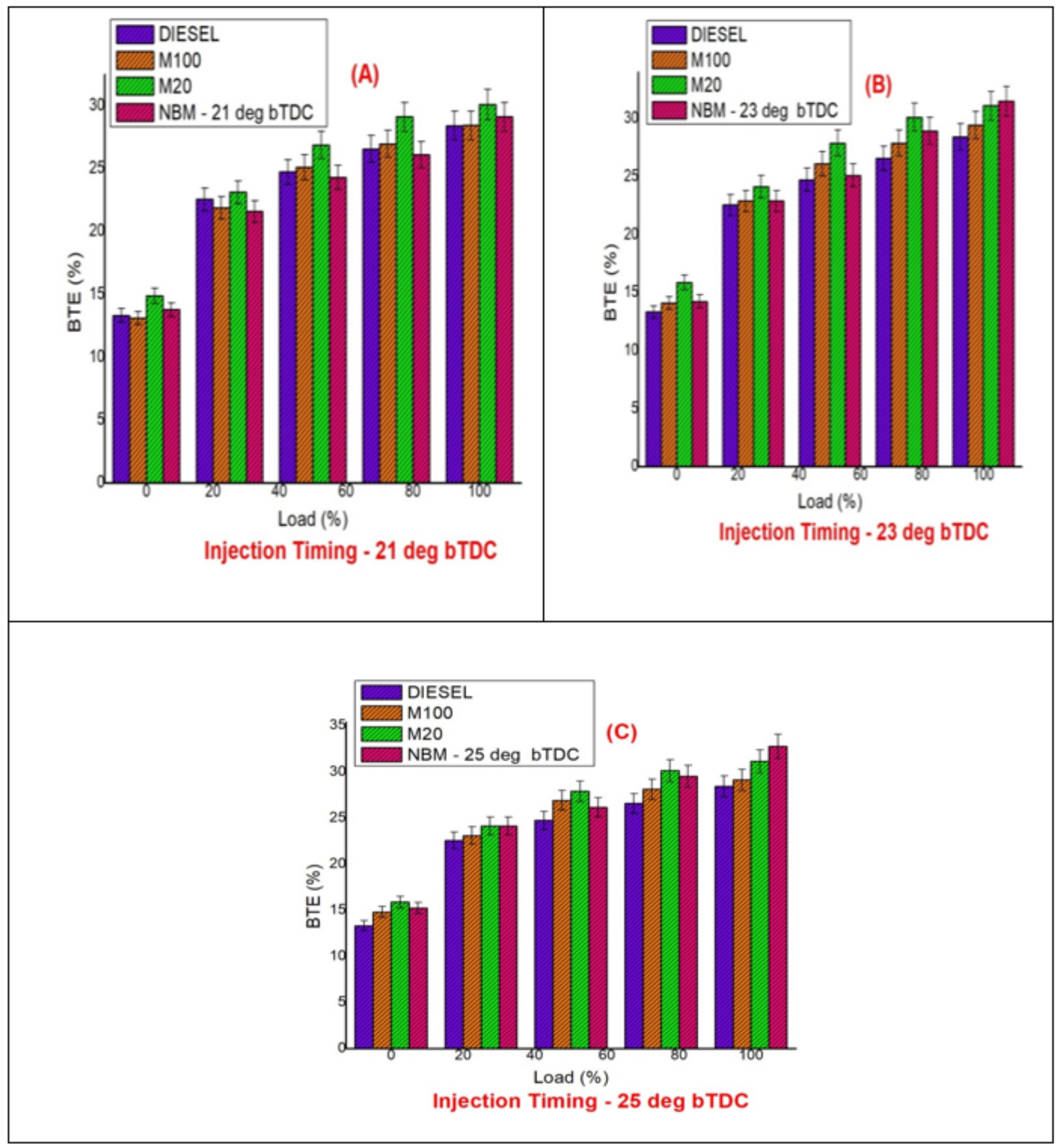

Figure 11

Variation of load vs. BTE at various blends (a) $21^{\circ} \mathrm{CA}$ bTDC, (b) $23^{\circ} \mathrm{CA}$ bTDC, and (c) $25^{\circ} \mathrm{CA}$ bTDC 


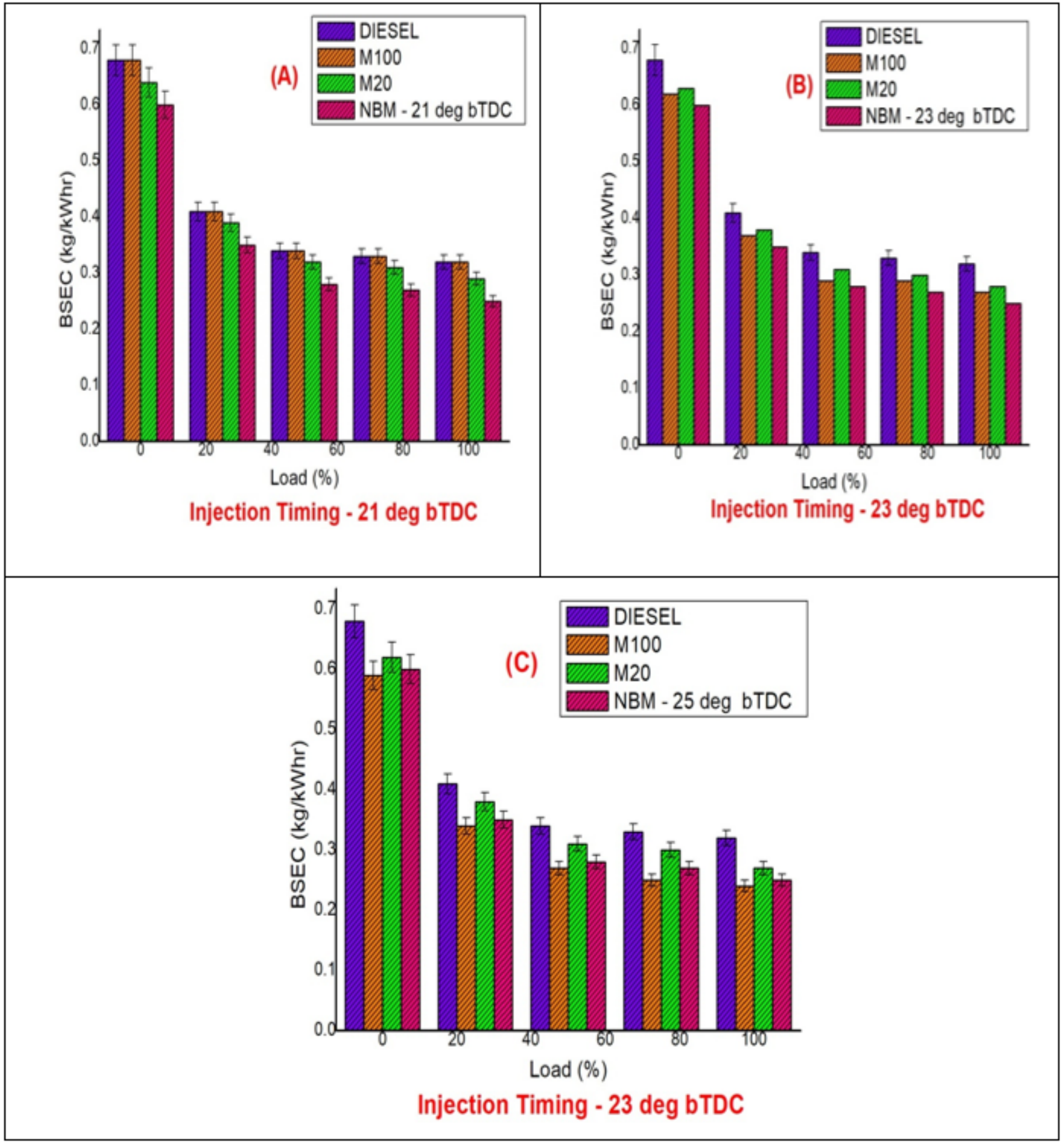

Figure 12

Variation of load vs. BSEC at various blends (a) $21^{\circ} \mathrm{CA} \mathrm{bTDC,} \mathrm{(b)} 23^{\circ} \mathrm{CA} \mathrm{bTDC}$, and (c) $25^{\circ} \mathrm{CA}$ bTDC 


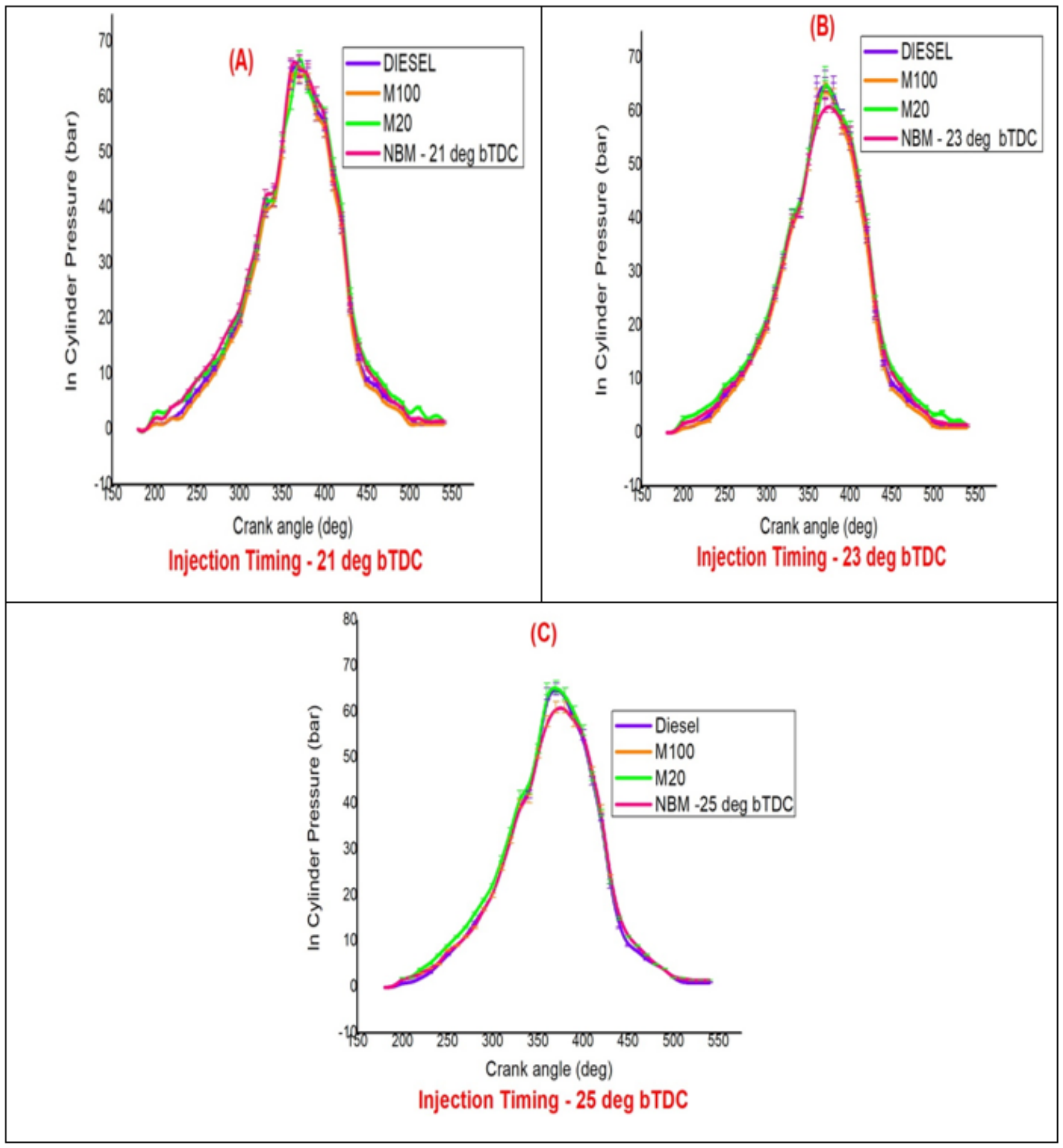

Figure 13

Variation of crank angle vs in-cylinder pressure at various blends (a) $21^{\circ} \mathrm{CA}$ bTDC, (b) $23^{\circ} \mathrm{CA} \mathrm{bTDC}$, and (c) $25^{\circ} \mathrm{CA}$ bTDC 


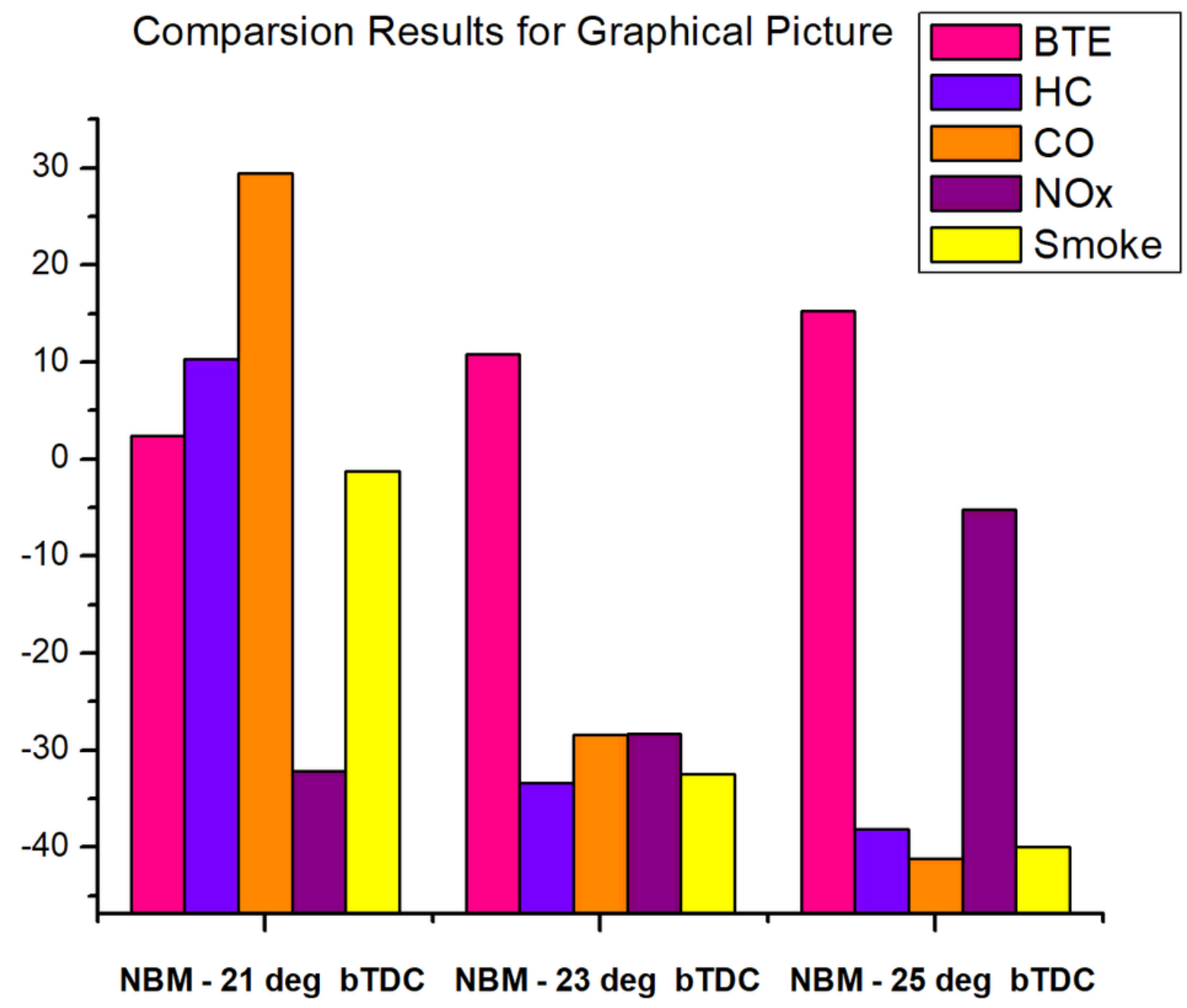

Figure 14

Graph depicting the comparison results of performance and emission characteristics

\section{Supplementary Files}

This is a list of supplementary files associated with this preprint. Click to download.

- Table78and9.docx 